\title{
The Lithic Artifacts of Indians at the Spanish Colonial Missions, San Antonio, Texas
}

Daniel E. Fox

Center for Archaeological Research

Follow this and additional works at: https://scholarworks.sfasu.edu/ita

Part of the American Material Culture Commons, Archaeological Anthropology Commons, Environmental Studies Commons, Other American Studies Commons, Other Arts and Humanities Commons, Other History of Art, Architecture, and Archaeology Commons, and the United States History Commons

Tell us how this article helped you.

This Article is brought to you for free and open access by the Center for Regional Heritage Research at SFA ScholarWorks. It has been accepted for inclusion in Index of Texas Archaeology: Open Access Gray Literature from the Lone Star State by an authorized editor of SFA ScholarWorks. For more information, please contact cdsscholarworks@sfasu.edu. 


\section{The Lithic Artifacts of Indians at the Spanish Colonial Missions, San Antonio, Texas}

\section{Creative Commons License}

\section{(c) (1) (8)}

This work is licensed under a Creative Commons Attribution-NonCommercial 4.0 International License 
THE LITHIC ARTIFACTS OF INDIANS

AT THE SPANISH COLONIAL MISSIONS,

SAN ANTONIO, TEXAS

Daniel E. Fox

Center for Archaeological Research

The University of Texas at San Antonio

Special Report, No. 8

1979 
LIST OF TABLES. ......................... . $i_{i}{ }_{i}$

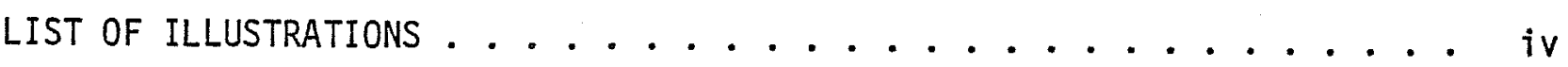

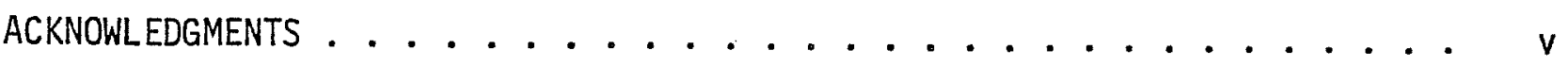

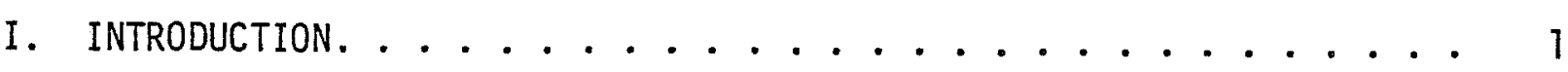

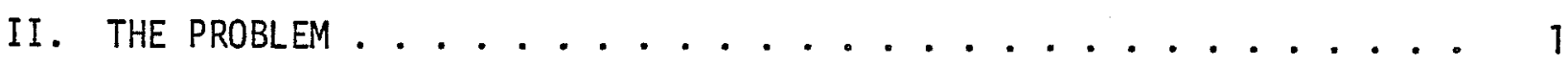

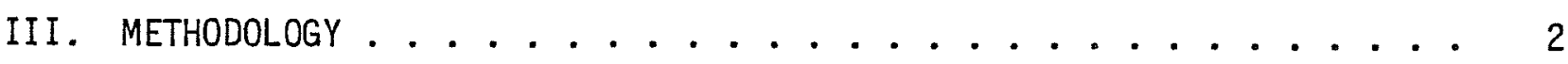

IV. THE SAN ANTONIO MISSION SITES . . . . . . . . . . . . 2

Historic Background. . . . . . . . . . . . 3

Archaeological Background. . . . . . . . . . . 3

V. THE SAMPLE. ...................... 7

VI. THE ANALYSIS. .................... 7

Cores.......................... 9

Core-Tools ...................... 13

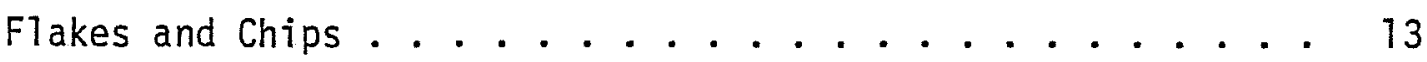

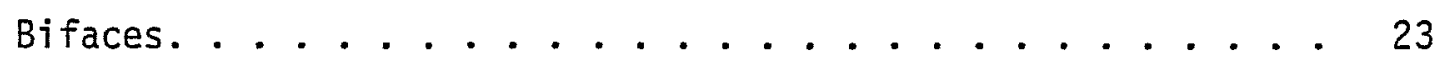

Gunflints and Strike-0-Lites ........... 26

Possible Gunflints . . . . . . . . . . . . 28

VII. IDENTIFICATION OF SPANISH COLONIAL PERIOD LITHICS . . . . . . . 28

Chronological Association Within Each Site . . . . . 29

Comparisons Between Collections. . . . . . . . . . 29

Comparisons With Other Collections ........... 32

Summary of Spanish Colonial Period Chipped Stone . . . . . 35 
Page

VIII. INTERPRETATION OF TECHNOLOGY. .................. 35

IX. DISCUSSION. ................. 37

REFERENCES CITED .................... 41 


\section{LIST OF TABLES}

Page

1. Inventory of Study Site Investigations . . . . . . . . . . . 8

2. Provenience of the Study Sample. . . . . . . . . . . . . . . 30

3. Comparative Collections. . . . . . . . . . . . . . . . . 34

4. Probable and Possible Spanish Colonial Chipped Stone . . . . . . . 36 


\section{LIST OF ILLUSTRATIONS}

Figure

Page

1. Lithic Processes and Definition. ........... 10

2. Classification Scheme for the Study Sample . . . . . . . . 11

3. Cores..................... 12

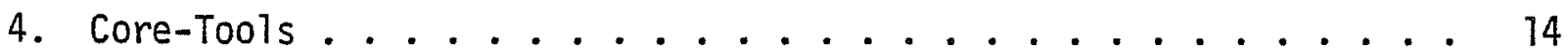

5. Utilized Flakes and Chips................ 17

6. Trimmed Flakes and Chips............... 18

7. Trimmed Flakes and Chips............. 19

8. Trimmed Flakes and Chips.............. 20

9. Bifaces. ................... 24

10. Bifaces......................... 25

11. Gunflints and Strike-0-Lites and Possible Gunflints. . . . . . . 27

12. Products and By-Products of Mission Lithic Tool Production . . . . 38

Map

1. Texas and Northern Mexico: Sites and Physiographic Featu es . . 4

2. The San Antonio Area During the Spanish Colonial Period. . . . . 5 


\section{ACKNOWLEDGMENTS}

This monograph is a slightly modified version of a masters thesis submitted to Texas Tech University. I wish to thank the members of my thesis committee -Dr. William J. Mayer-0akes, Chairman, and Dr. Richard Keslin of the Department of Anthropology at Texas Tech University, and Curtis D. Tunne11, the State Archeologist of Texas -- for the patience, advice and encouragement that they have afforded me in the preparation of the thesis.

I especially appreciate the help I have always received from the staff at the Office of the State Archeologist in Austin and at the Center for Archaeological Research, The University of Texas at San Antonio, and their assistance during the research phase of the thesis project.

I also am deeply indebted to Linda Austin who typed the final draft of this thesis. Typing for publication was done by Alice Morici and Amarinthia Gretzinger. The report has been edited by Elizabeth Branch and Thomas R. Hester. 


\section{INTRODUCTION}

Prior to 1962, no Spanish Colonial mission in Texas had been investigated by trained archaeologists (Tunnell and Newcomb 1969:iii). Since then, a number of Texas mission sites have received the attention of archaeologists and ethnohistorians, and in recent years the potential for the study of culture process through the interdisciplinary efforts of archaeological and ethnohistorical research has been recognized (Campbel1 1973, 1975).

Disparities between the methodological assumptions of ethnohistorians and archaeologists, however, have tended to reduce effective cooperation of the disciplines. Although their ultimate objective is to study and explain the processes of culture change, prehistoric archaeologists must first construct local and regional culture sequences and correlate late prehistoric culture units with the historic ethnic groups recorded by the first European travelers and explorers. Ethnohistorians, on the other hand, are attracted more to those bodies of data which are more complete, more informative, and more readily available than the earliest accounts. Confronted with a complicated, unsystematized assortment of ethnographic data, it is understandable that archaeoologists, as amateur ethnohistorians, tend to make little more than minimal or ineffective use of ethnohistorical material (Campbell 1973:4).

The development of a systematized ethnohistory for Texas researchers will, no doubt, take time. Meanwhile, recovery of threatened archaeological material and preservation, where possible, must keep pace with increasing deterioration and destruction of Spanish Colonial sites, especially mission sites which appear to have the earliest known culture assemblage that can be attributed confidently to specific historic Indian groups (Tunnell and Newcomb 1969:iii). Stemming from this, a major problem for current archaeological research in Texas concerns the formulation of techniques which will allow effective utilization of presently available cultural data from mission site investigations in ongoing problem-oriented ethnohistorical/archaeological research.

The purpose of this study is to define and morphologically describe an assemblage of lithic cultural material thought to be representative of a group of Spanish Colonial mission sites in Texas.

\section{THE PROBLEM}

By the beginning of the mission period in Texas the native peoples of the area had been subjected to over 200 years of population decline, territorial displacement, segregation, ideological pressure, loss of ethnic identity, and absorption by invading populations (Campbell 1973:2). It seems logical that European tools and mission technology quickly replaced the hunting and gathering technology of native groups. One technological system which was retained at least for a short period was the manufacture and use of lithic tools.

Archaeological reports on mission investigations have devoted only minimal attention to lithic collections and have presented little more than simple descriptive inventories of 1 ithic material recovered. Many published analyses are inadequate for the purposes of intersite comparison. 
Most authors concentrate on the analysis of European-introduced materials because they can be associated easily and more reliably with particular functions and specific time spans. It seems doubtful, however, that this emphas is on European-made material culture will aid in the study of acculturation or other processes of culture change involving later prehistoric aboriginal populations in Texas.

A major problem is the lack of intensive analyses of Texas mission period chipped stone materials, especially analyses aimed at comparative and processual interpretation:* This is the matter to be addressed in this monograph.

\section{METHODOLOGY}

The proposed solution to the above stated problem is to identify and morphologically describe an assemblage of chipped stone considered to be representative of the Spanish Colonial Period occupation of mission sites in San Antonio, Texas. Operations include:

1) The selection of a group of archaeological sites which are comparative on the basis of geography, culture, and time; i.e., the Spanish Colonial missions of San Antonio, Texas.

2) The location of samples of lithic artifacts recovered during archaeological investigations at these sites.

3) The analysis and description of a sample of these lithics, following a consistent morphological classificatory scheme.

4) Identification of Spanish Colonial Period chipped stone, considering the possibility of mixture with lithic material deposited during prehistoric occupations of the mission sites.

5) The interpretation of the 7 ithic technology represented in terms of the processes involved in the manufacture of chipped stone tools recovered from the different mission sites.

As a concluding procedure, some speculation concerning past cultural phenomena, such as technological and possibly sociocultural change related to culture contact, can be offered based on the careful description of the data assembled.

\section{THE SAN ANTONIO MISSION SITES}

The Spanish Colonial missions of the San Antonio area in Bexar County, Texas, were selected as a group of geographically, temporally and culturally related archaeo-

* Since this manuscript was written, Hester (1977) has published a brief account of the mission lithics from San Juan Bautista and San Bernardo, Coahuila. This paper also contains comparative data on lithic assemblages at certain Texas missions (see also Hester 1975b, 1976a). 
logical sites. San Antonio is situated on the northern edge of the South Texas Plain, just below the abrupt and rugged southeastern margin of the Balcones Escarpment. As such, various mineral, plant and animal resources of two major physlographic regions, the Edwards Plateau and the West Gulf Coastal Plain, were accessible to exploitation by an eighteenth century Spanish Colonial frontier community (Map 1). The native inhabitants of these regions were also an important resource.

\section{Historic Background}

At the beginning of historic times (by the late sixteenth century), south Texas was occupied general1y by Coahuiltecan-speaking, maritime-adapted and savannaadapted hunting and gathering groups (Hester 1976b). Plains-adapted Tonkawa and Lipan Apache peoples, and, during the eighteenth century, Comanche immigrants, occupied the central Texas area (Newcomb 1960).

San Antonio had its beginnings in 1718 with the founding of Mission San Antonio de Valero (the Alamo) and the establishment of the Presidio San Antonio de Bexar (Map 2). Mission San José y San Miguel de Aguayo was founded there in 1720, and during the following 11 years, Missions Nuestra Señora de la Purísima Concepción de Acuña, San Juan Capistrano and San Francisco de Espada, a11 originally established in East Texas in 1716, were refounded nearby along the San Antonio River (Habig 1968:xvii-xviii, 3; Ramsdel1 1968:15-16, 124).

In 1731, a group of Canary Islanders founded the Villa San Fernando and its church near the Presidio on the west bank of the San Antonio de Valero (Habig 1968:38). Financed by the Spanish crown, these colonists were brought to occupy the territory and to set an example for the mission neophytes (Schuetz 1968:11).

During the eighteenth century, the five missions developed through hardships and successes. Although troubled by Apache and Comanche raids, disease, political pressure and the difficulty of keeping new Indians around long enough to "civilize" them (Habig 1968:35-36, 39-43; Ramsdell 1968:17-18, 24-29), the San Antonio chain of missions succeeded in Christianizing and otherwise acculturating a great many native Texans (Habig 1968:57). These included particularly Coahuiltecans, Karankawa, Apache and probably even a few Comanche (Santos 1966). Many mission Indians became an integral part of the San Antonio civil community (Schuetz 1968:53).

By the late eighteenth century, the development of the missions and the civil settlement of San Antonio was declining steadily (Habig 1968:81-91). The partial secularization of the missions took place during the 1790s (Habig 1968:85, 102-106; Ramsdel1 1968:18, 136). By 1824, all five were completely secularized, ceased to be missions, and began to fall into ruin (Habig 1968:123; Ramsdel1 1968:125).

Archaeological Background

In recent years over 17 intensive and short-term archaeological investigations have been undertaken at the five we11-known San Antonio missions, and at three other important Spanish Colonial Period sites in the vicinity. 


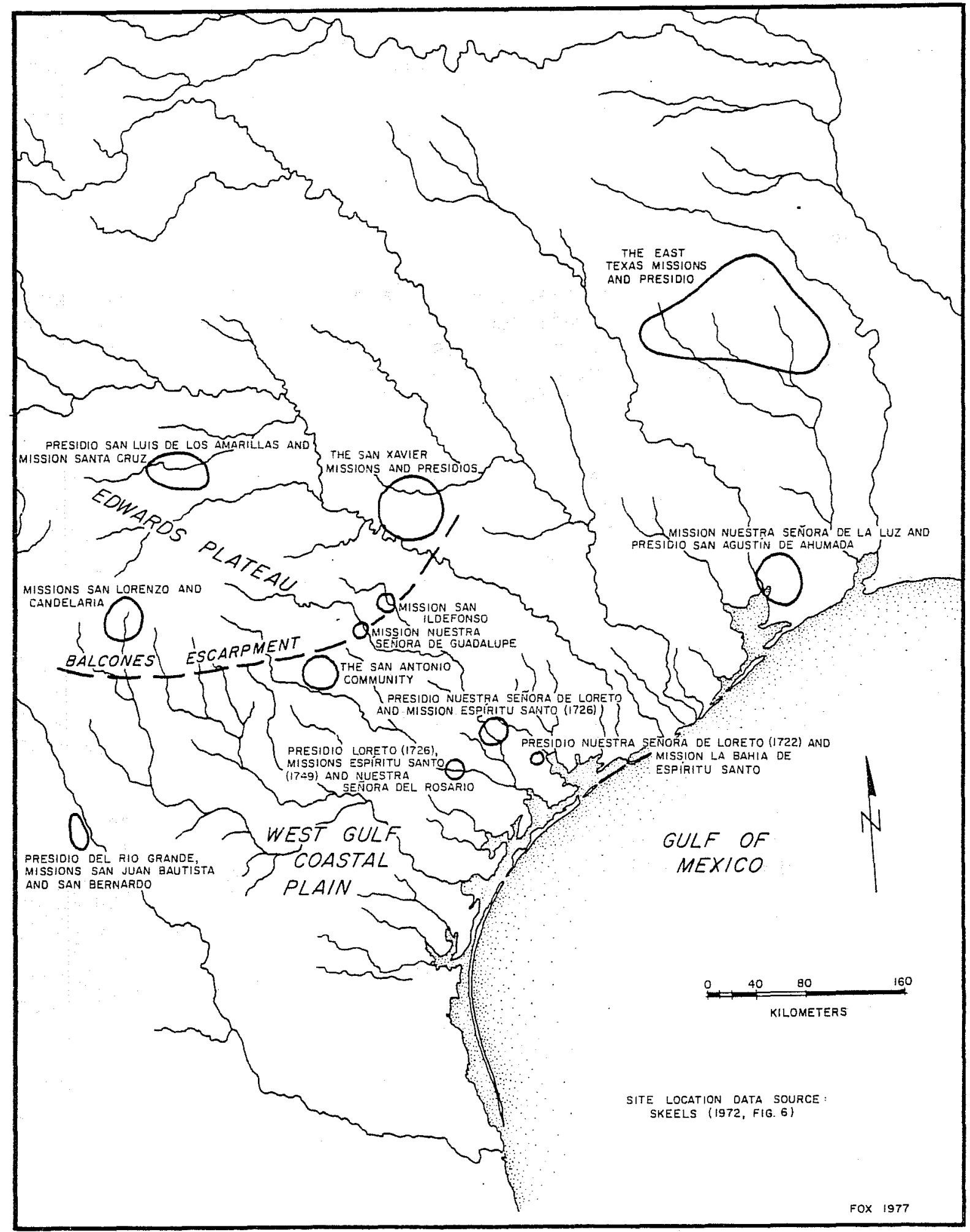

Map 1. Texas and Northern Mexico: Sites and Physiographic Features. 


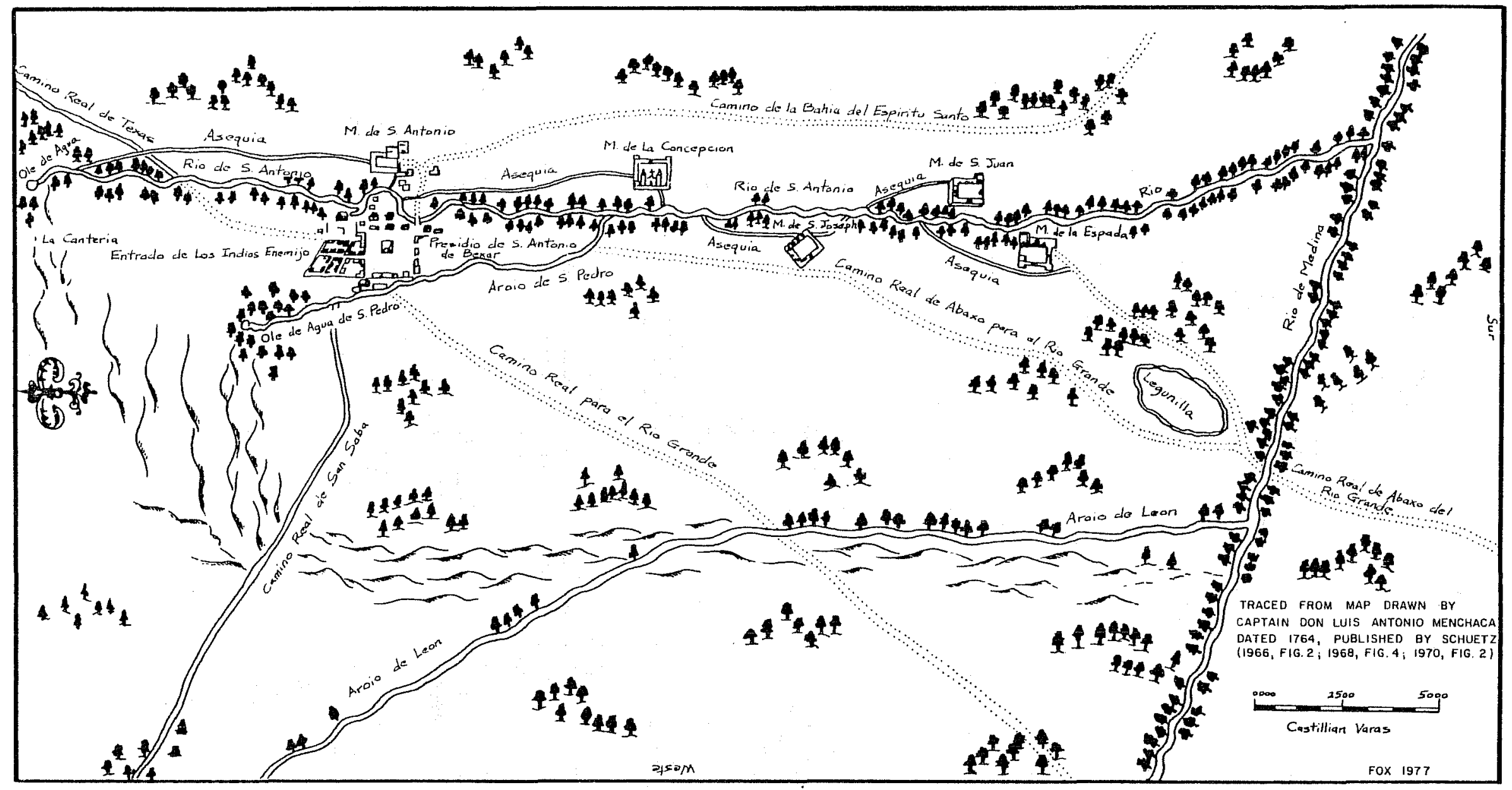

Map 2. The San Antonio Area During the Spanish Colonial Period. 
In 1966, with a grant provided by the State Building Commission as part of their archaeological program, the Witte Memorial Museum conducted an archaeological excavation at Mission San Antonio de Valero (the Alamo). Under the direction of Mardith $K$. Schuetz and John Greer, work in the convento area of the site yielded significant stratigraphic, architectural and artifactual information (Schuetz 1966; Tunne11 1966; Greer 1967). In 1970, the footings of nineteenth century structures and the location of a portion of the acequia (or mission aqueduct) were revealed during investigations north of the D.R.T Library by Willtam M. Sorrow (1972). In 1973, excavations in the Second Patio area by Mardith Schuetz (1973) recovered additional information. An area east of the museum building was tested by a crew of graduate students from The University of Texas at San Antonio in November 1973 (Adams and Hester 1973). The more recent archaeological investigation of the Alamo was undertaken in 1973 as a systematic search for evidence of the south wall of the mission compound and its related buildings (Fox, Bass and Hester 1976).

Similar salvage-type archaeological work has been done at Mission San José y San Miguel de Aguayo (Fox 1970; Schuetz 1970; Clark 1978) and at Mission San Francisco de la Espada (Fox and Hester 1976). An interesting study of evidence of the Spanish Colonial sugar industry at Mission San José has recently been published (Clark 1976).

Intensive archaeological investigation of Mission San Juan Capistrano was begun in 1967 as part of the archaeology program of the State Building Commission, in cooperation with the Archdiocese of San Antonio (Schuetz 1968, 1969). Under the direction of Mardith Schuetz and the general supervision of the State Archeologist, Curtis Tunnell, a team of amateur and professional investigators sought to recover a sample of artifacts and skeletal remains of the mission Coahuil tecan Indians, as well as architectural data. This work and further investigations of the mission chapel (Schuetz 1974) and convento were prompted by plans for the restoration of various structures at Mission San Juan.

In 1971 and 1972, extensive archaeological excavations were carried out at Mission Nuestra Señora de la Purisima Concepción de Acuña. Crews directed by Dan Scurlock of the Texas Historical Commission obtained information pertaining to foundation-moisture conditions of the extant structures at the mission, and succeeded in locating and studying the remains of portions of the compound wal1, the stone quarry and other features in the west compound area of the site (Scurlock and Powers 1975; Scurlock and Fox 1977).

In addition to the five missions, at least three other Spanish Colonial Period sites in San Antonio have received attention. In 1966, a segment of the Acequia Madre was studied in preparation for HemisFair '68 (Schuetz 1970). During the spring and summer of 1975, salvage investigations were made beneath the floor of San Fernando Cathedral (originally the secular church of the Villa de San Fernando) in downtown San Antonio (Fox, Scurlock and Clark 1977). In 1976, test excavations were carried out at the Governor's Palace, located across Military Plaza from the San Fernando Cathedral (Fox 1977).

In sum, all of the significant archaeology done at Spanish Colonial Period sites in San Antonio were salvage-type, short-term and intensive excavations. Problem orientations were adapted to limitations of time and money, and dealt with the recovery of basic architectural and artifactual data. Although some attempts 
have been made to interpret data by site (see, for example, Clark 1976; Schuetz 1969; Fox, Scurlock and Clark 1977), as yet no synthesis of the Spanish Colonial Period archaeology of the San Antonio area has been published.

\section{THE SAMPLE}

Most of the data recovered from previous Spanish Colonial Period archaeology of the San Antonio area has been published. Notes, artifact collections and samples of faunal remains and soils (from some sites) are stored at institutions located in San Antonio and Austin, Texas. However, due to limitations of time and money, the location, observation and analys is of all of the chipped stone collected from San Antonio missions are beyond the scope of this study project. Instead, five collections were selected, representing five different archaeological investigations at four missions.

Table 1 summarizes the nature of these lithic collections. Although the five collections represent less than one-third of the number of archaeological investigations undertaken, judging from the total number of 1ithic artifacts reported in the literature, the study sample probably amounts to more than two-thirds of the chipped stone recovered and preserved from Spanish Colonial Period sites in the San Antonio area.

\section{THE ANALYSIS}

For many years the descriptive classification of chipped stone cultural materials has been the basis for much of the interpretation of the prehistory of various parts of the world (Tax 1975:v). Recently, archaeologists have been approaching classification as a means to an end, rather than as an end in itself.

...the observable physical characteristics of our subject material (sites and artifacts) must be connected in a model with at least some conceptual terms which encompass these characteristics. That is, rather than compartmentalize according to differentiating criteria, we need to specify characteristics of our material along many axes and formulate some hypotheses about relations between them (Wilmsen $1974: 45)$.

The simple descriptive classification of chipped stone tools is being replaced by the study of lithic technology--the analys is of attributes or chipped stone forms representative of processes of lithic tool production. Since many such processes are thought to be universal, and because of an increasing need for communication between students of lithic technology (Bradiey 1975:5-12; Movius 1974:112), there is a trend toward standardization of techniques and terminology related to the analys is of chipped stone.

However, there also is a need for continued communication of information between archaeologists working within traditional regions. The following analysis of the sample of chipped stone from Spanish Colonial mission sites in San Antonio 
TABLE 1. INVENTORY OF STUDY SITE INVESTIGATIONS

\begin{tabular}{|c|c|c|c|c|c|c|}
\hline Mission & $\begin{array}{l}\text { Date of } \\
\text { Invest1- } \\
\text { gation }\end{array}$ & Archeolog1st & Reference & $\begin{array}{l}\text { Location of } \\
\text { Collections }\end{array}$ & $\begin{array}{l}\text { Total } \\
\text { Lithics } \\
\text { Studied } \\
\end{array}$ & Sampling Informat ion \\
\hline Concepción & $\begin{array}{l}1971, \\
1972\end{array}$ & $\begin{array}{l}\text { Dan Scurlock } \\
\text { (Texas Histori- } \\
\text { cal Commission) }\end{array}$ & $\begin{array}{l}\text { Scurlock } \\
\text { and Powers } \\
1975 ; \text { Scur- } \\
\text { lock and Fox } \\
1977\end{array}$ & $\begin{array}{l}\text { Texas Histori- } \\
\text { cal Commission } \\
\text { Aust in }\end{array}$ & 969 & $\begin{array}{l}93 \text { test pits of sizes ranging from } 1 \times 1 \text { meters to } \\
2 \times 4 \text { meters, excavated in arbitrary levels, and } \\
\text { screened through } 1 / 4-1 \text { inch and } 1 / 2-1 \text { nch hardware cloth. } \\
\text { Material culture catalogued in relation to test pit and } \\
\text { level designations. Test pits were placed in and } \\
\text { around extant structures, and in the west conpound } \\
\text { area of the site. }\end{array}$ \\
\hline $\begin{array}{l}\text { San José } \\
\text { (41BX3) }\end{array}$ & 1974 & $\begin{array}{l}\text { John Clark } \\
\text { (Texas Histori- } \\
\text { cal Commission) }\end{array}$ & Clark 1978 & $\begin{array}{l}\text { Texas Histori- } \\
\text { cal Conmission } \\
\text { Aust in }\end{array}$ & 126 & $\begin{array}{l}\text { Seven } 1 \times 2 \text { meter test pits and one } 1 \times 3 \text { meter unit, } \\
\text { excavaced in } 20 \text {-cm arbitrary levels, and screened } \\
\text { through } 1 / 4 \text {-inch hardware cloth. Test pits located } \\
\text { inside and outside walls of mission compound. Arti- } \\
\text { facts catalogued by test pit and level. }\end{array}$ \\
\hline $\begin{array}{l}\text { San José } \\
\text { (4.1.1.X3) }\end{array}$ & 1.968 & $\begin{array}{l}\text { Mardith Schuetz } \\
\text { (Witte Memorial } \\
\text { Museum; State } \\
\text { Building Conmis- } \\
\text { sion) }\end{array}$ & $\begin{array}{l}\text { Schuetz } \\
1970\end{array}$ & $\begin{array}{l}\text { Center for } \\
\text { Archaeological } \\
\text { Research, The } \\
\text { University of } \\
\text { Texas at San } \\
\text { Antonio }\end{array}$ & 96 & $\begin{array}{l}\text { A series of screened }(1 / 4-\text { inch mesh) areas along } \\
\text { trenches for a sprinkler system; samples from } \\
\text { areas near the north wall of the convento, west of } \\
\text { the west compound wall, and in the eastern portion } \\
\text { and the southwest corner of the compound. Some } \\
\text { material catalogued by screened areas. }\end{array}$ \\
\hline & & & & & & \\
\hline $\begin{array}{l}\text { San Antonto } \\
\text { de Valero }\end{array}$ & 1973 & $\begin{array}{l}\text { Mardith Schuetz } \\
\text { (Witte Memortal } \\
\text { Museum; Texas } \\
\text { listorical com- } \\
\text { misston) }\end{array}$ & $\begin{array}{l}\text { Schuetz } \\
1973\end{array}$ & $\begin{array}{l}\text { Center for } \\
\text { Archaeological } \\
\text { Research, The } \\
\text { University of } \\
\text { Texas at San } \\
\text { Antonio }\end{array}$ & 53 & $\begin{array}{l}\text { Eight } 10 \times 10 \text { foot, three } 5 \times 10 \text { foot, three } 5 \times 5 \text { foot } \\
\text { excavation units, and one unit with an area of } 137 \\
\text { square feet, excavated in four supposed occupational } \\
\text { levels. Upper three levels screened through } 1 / 2-\text { inch } \\
\text { hardware cloth; level four through } 1 / 4-1 \text { nch and } 1 / 2-1 \text {-Inch } \\
\text { mesh. Excavation untes located fn an area within the } \\
\text { present Alamo walls. Most artifacts catalogued by level } \\
\text { and unit. }\end{array}$ \\
\hline $\begin{array}{l}\text { San Juan } \\
\text { Capistrano } \\
\text { (41BX5) }\end{array}$ & 1967 & $\begin{array}{l}\text { Mardith Schuetz } \\
\text { (Witte Memorial } \\
\text { Museum; State } \\
\text { Build Ing Cont- } \\
\text { mission) }\end{array}$ & $\begin{array}{l}\text { Schuetz } \\
1968,1969\end{array}$ & $\begin{array}{l}\text { Center for } \\
\text { Archaeological } \\
\text { Research, The } \\
\text { University of } \\
\text { Texas at San } \\
\text { Antonio }\end{array}$ & 1,085 & $\begin{array}{l}\text { Fill from entire rooms and portions of rooms along com- } \\
\text { pound walls, portions of the church nave and baptistry, } \\
\text { an area in the northwest corner of the compound, and } \\
\text { a mound of displaced room fill or thidden deposit outside } \\
\text { the southwest corner of the compound. All removed in } \\
6-i \text { ch levels and screened through } 1 / 4-\text { inch and } 1 / 2 \text { inch } \\
\text { hardware cloth. Most lithics catalogued by level and } \\
\text { room or unit number, and counted in pounds and ounces. }\end{array}$ \\
\hline
\end{tabular}


is adapted from a classification scheme which has proved to be useful for comparative interpretation of lithics recovered during various archaeological investigations at prehistoric and historic sites in central and south-central Texas (Briggs 1971; Mallouf, Fox and Briggs 1973; Scurlock and Fox 1977). Although this classification scheme might be considered somewhat regional (Fig. . 1), the descriptive data are presented in such a way that they can be used in a broader disciplinary context (see Bradley 1975).

Comprising the sample of five collections from archaeological investigations at four San Antonio mission sites, 2,329 chipped stone artifacts are sorted into morphologically defined categories (Fig. 2). This classification scheme is as much a taxonomic system as it is an analytical one (see Rouse 1960). It is made up of morpho-technological classes and subclasses, al1 of which are presented for the purposes of tentative typological description and comparison, and some of which can be considered to be representative of processes involved in the manufacture of chipped stone tools. As such, the morphologically defined categories may be representative of products (chipped stone specimens which functioned as tools) and by-products (chipping debris and other lithic forms which became detached from the continuum) of lithic tool production.

The size range of lithic specimens in most categories and respective subcategories can be determined from accompanying illustrations which show the artifacts actual size. Sizes of specimens in some categories are included in the text when dimensions are necessary for an adequate morphological description of those categories. Whenever possible, the more distinct forms (products or by-products) are compared to similar morphologically defined forms from other areas.

Cores (41 specimens; Fig. 3,a-c)

A core is any nodule or cobble from which a flake or flakes have been removed. Comprising $1.7 \%$ of the entire 11 thic sample, all 41 cores appear to have been produced from stream-worn chert gravels which probably were available locally during the Spanish Colonial Period, as they are today, along the stream channels and terraces of the San Antonio River and its tributaries. The cores vary in size (fist-size, or smaller) and in degree of reduction. Several smal1 specimens may be exhausted cores which were discarded because of limited surface area. Others probably were discarded because of noticeable flaws in material quality and resultant excessive hinge-fracturing. There is no apparent morphological evidence to explain why a variety of large cores were discarded. None of the specimens in this sample exhibits obvious signs of wear or burning.

Cores can be divided into two major subcategories for analytical purposes.

Cortex Platform (12 specimens; Fig. 3,a)

Cortex platform cores are chert cobbles from which only a few flakes have been struck from unprepared cortex surfaces. One small specimen (from Mission San José) is a small pebble which has two opposing striking platform areas. 


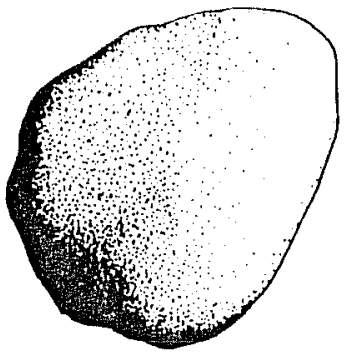

NODU LE

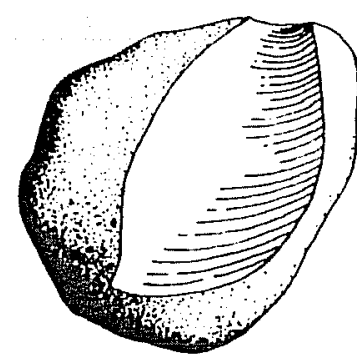

CORE

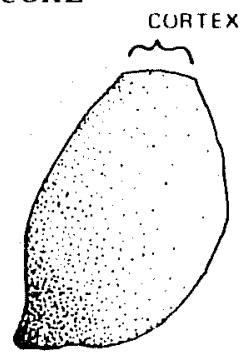

PRIMARY FLAKE

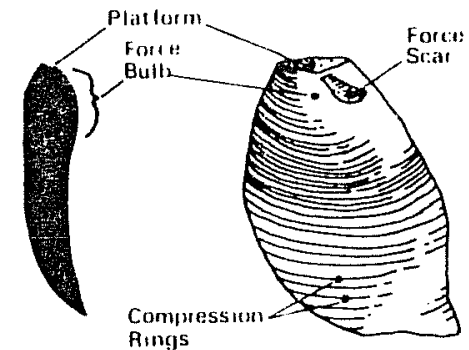

CROSS SECTION INTEANAL
SUAFACE EXTERNAL
SURFACE

ATTRIBUTES OF A FLAKE
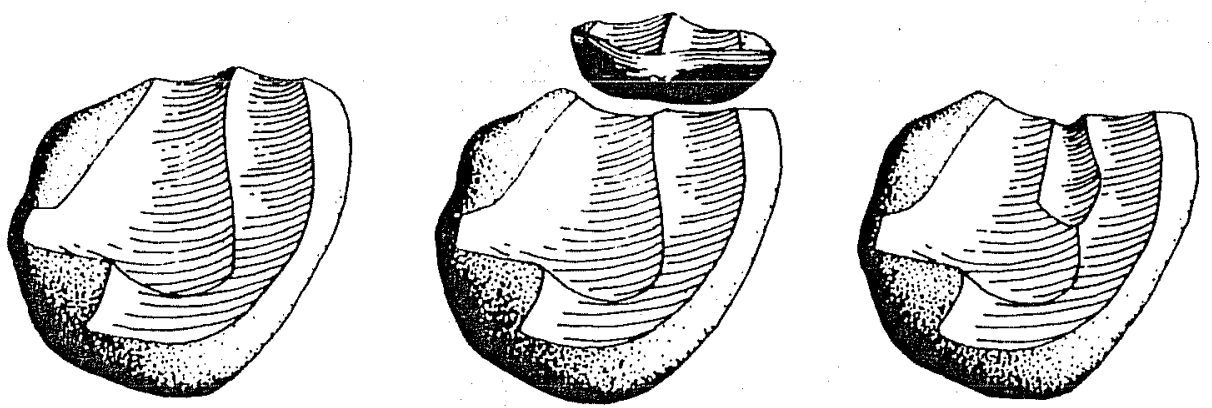

MULTIPLE ILARGEI FACET

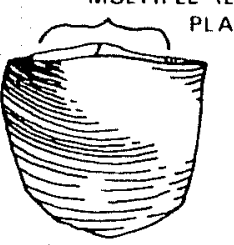

SECONDARY FLAKE

SECONDARY FLAKE
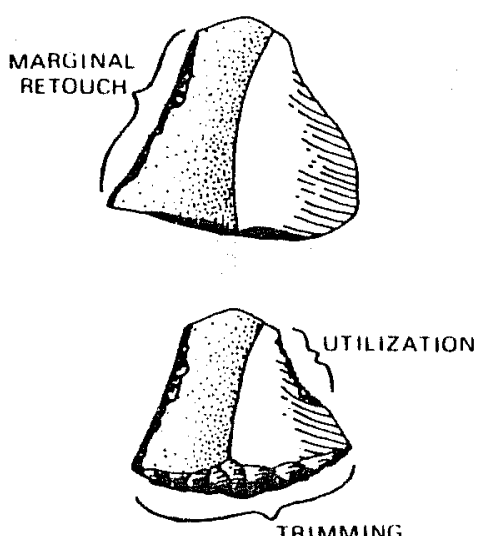

FINISHED UNIFACE
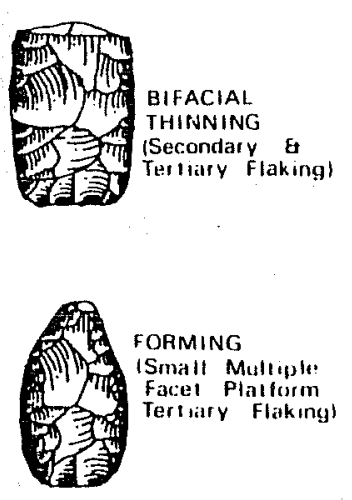

FINISHED BIFACE

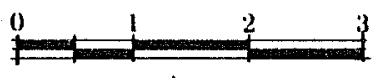

in.

Figure 1. Lithic Processes and Definition. 


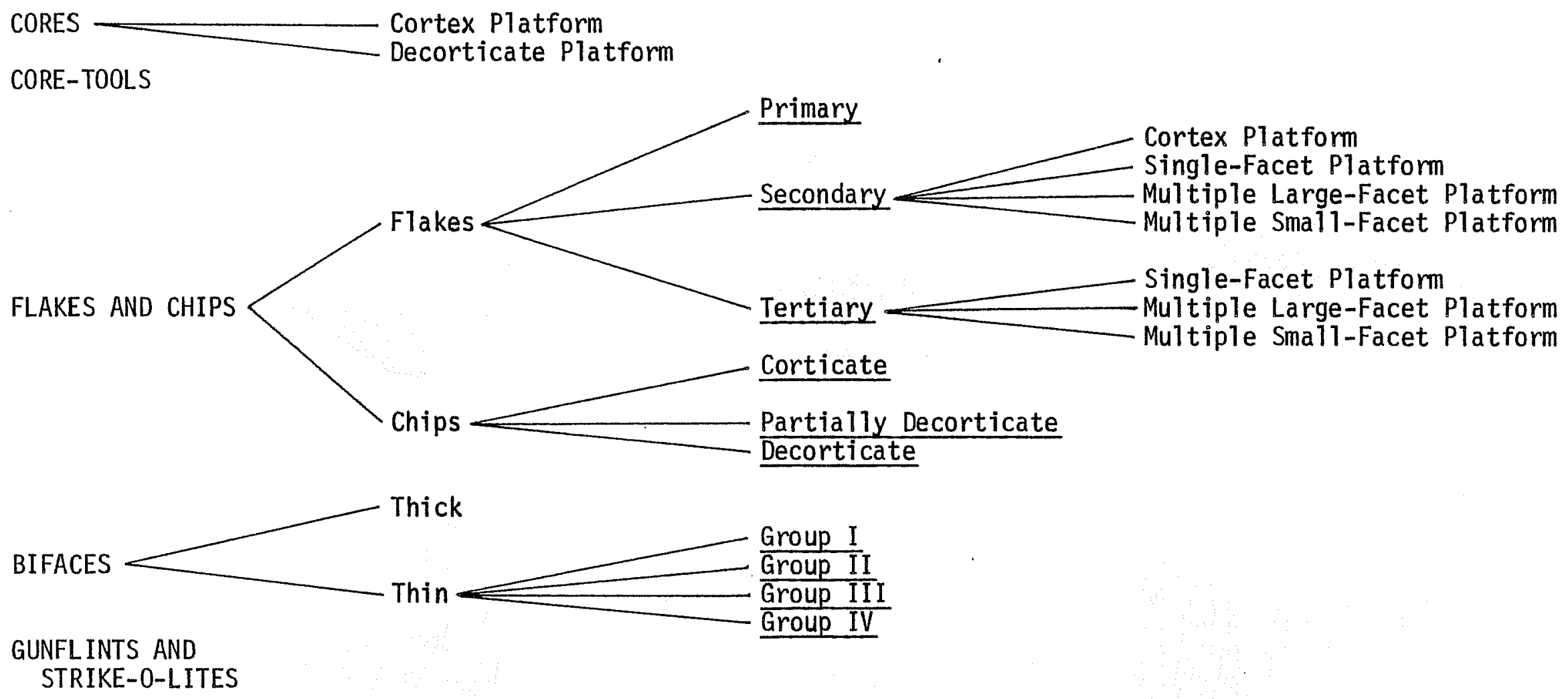

POSSIBLE GUNFLINTS

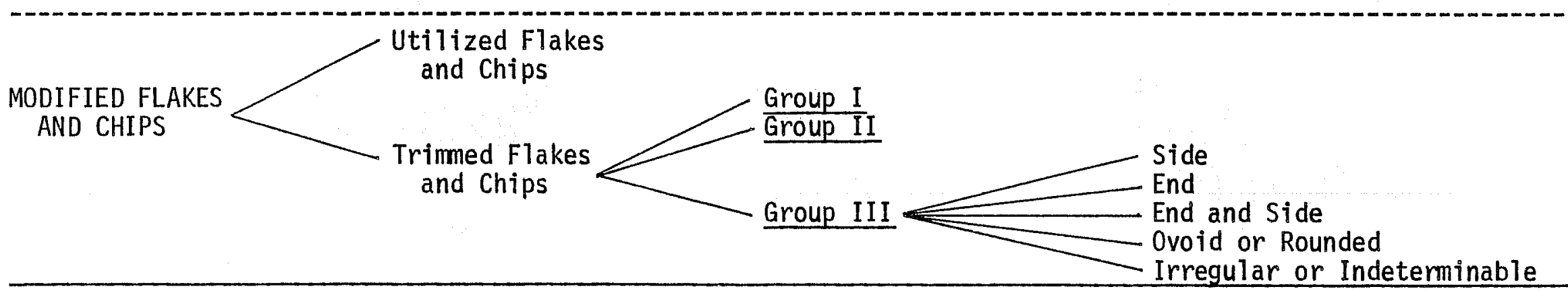

Figure 2. Classification Scheme for the Study Sample. 

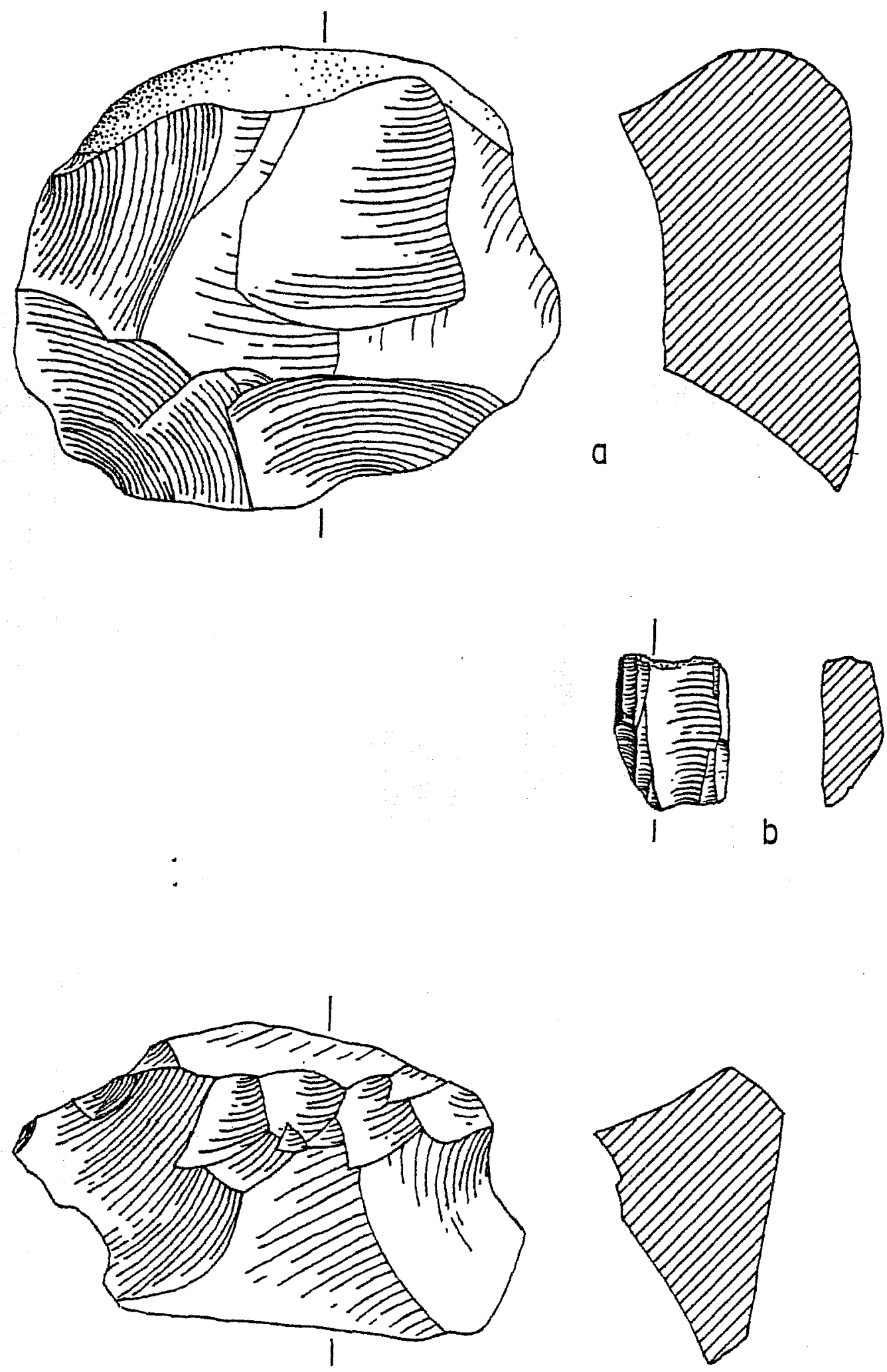

C

Figure 3. Cores. a, cortex platform (41 BX 3); b, c, decorticate platform (b, 41 BX $3 ; c, 41$ BX 12). 
Decorticate Platform (29 specimens; Fig. 3,b-c)

This category consists of cores which have been worked bifacially and multifacially with flake scars originating most often from single-facet platforms created by a previous flake removal, and less often from multiple-facet platforms formed by two or more flake scars. The crushed opposing platform areas of one small core (from Mission San Josê) may have been produced by bipolar percussion flaking (Fig. 3,b), as defined by Honea (1965) and Kobayashi (1975).

Core-Tools (7 specimens; Fig. 4,a-b)

The term "core-tool" applies to cores or large chert cobbles which appear to have been reduced so as to produce tools. Core-tools comprise $0.3 \%$ of the entire lithic sample.

Two specimens contained in the lithic collection from Mission San Juan Capistrano are similar in size and material type to previously described decorticate platform cores. Each of the San Juan specimens has been fashioned with a pointed end and may have served as a boring or cutting implement (Fig. 4,b).

The five remaining core-tools (from Mission Concepciôn) are chopper-like implements. Each is a pebble tool which retains cortex on one end and is bifacially flaked and battered on the opposite end (Fig. 4,a). The cortex ends of three specimens exhibit signs of battering which may be the result of the use of these core-tools as hammerstones. However, this battering of the cortex is directly opposite the chipped edges and could be the result of resting the cobble on a hard surface (or anvil) while flakes were struck from it.

\section{Flakes and Chips (2,142 specimens)}

Representing products and by-products of 7 ithic tool production, flakes and chips comprise $92.0 \%$ of the 7 ithic sample. Each flake retains a portion of the platform area at which force was applied to remove it. Chips are flake fragments which do not have platforms. Both unaltered and modified flakes and chips were first analyzed by being assigned to morphologically defined sub-categories. Modified (utilized and trimmed) flakes and chips were then subjected to a second classification. Therefore, the results of the first analysis include al1 specimens classified as flakes and chips, only a portion of which were further sorted into taxonomic categories of modified flakes and chips.

Flakes $(1,194$ specimens $)$

Flakes (51.3\% of the entire 1ithic sample) are sorted initially into categories based on the amount of cortex present. Further subdivision is presented by platform type. 

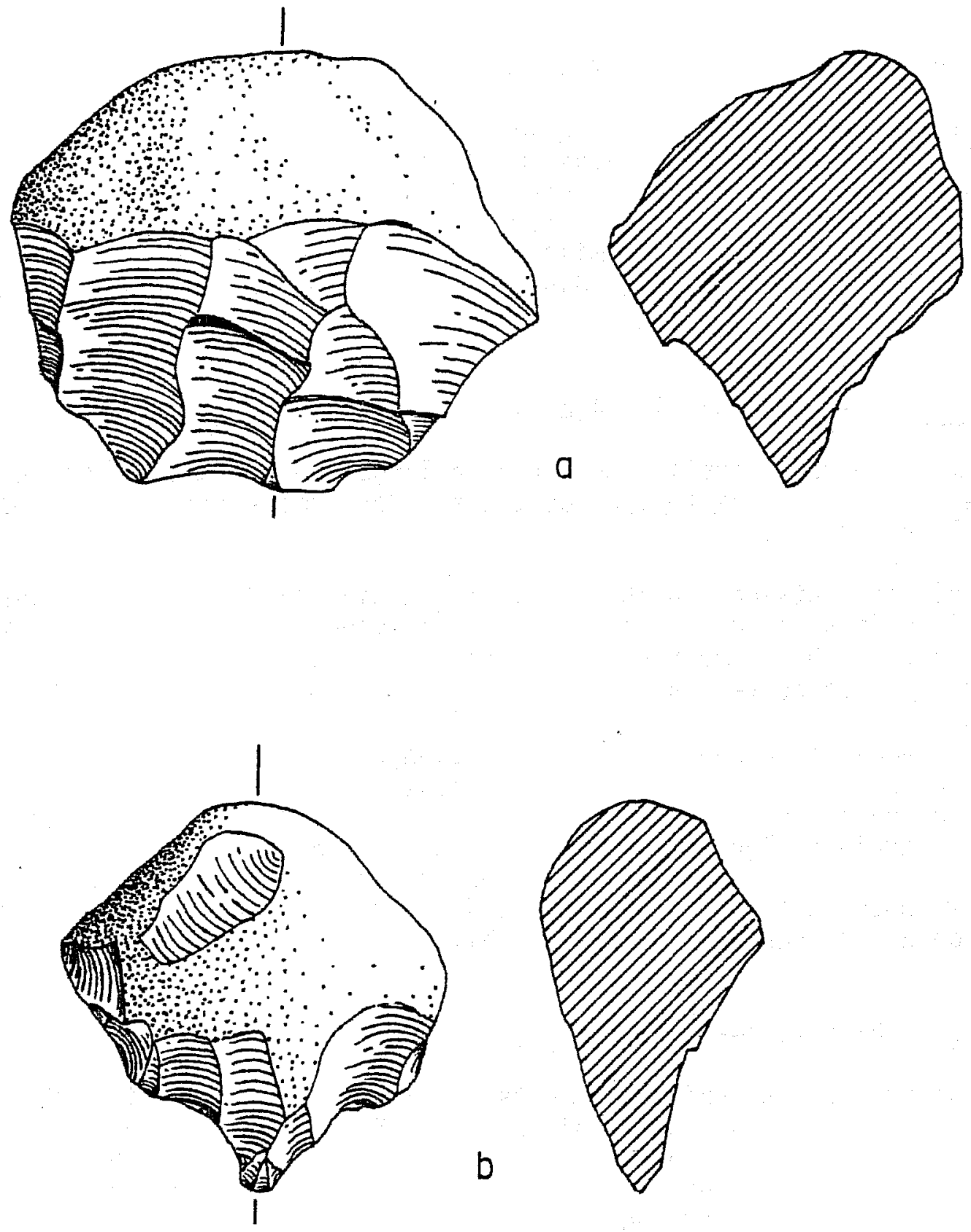

Figure 4. Core-Tools. a, $41 \mathrm{BX} 12 ; b, 41 \mathrm{BX} 5$. 


\section{Primary (24 specimens)}

Because a primary flake is produced as an initial removal from the unal tered exterior surface of a cobble or core, it has an unprepared cortex striking platform and retains cortex over its entire exterior surface.

Secondary (756 specimens)

Secondary flakes are partially decorticate, having been removed from partially decorticate portions of cores, flakes and bifaces. Struck from unprepared corticate or simply prepared decorticate platforms, most of the secondary flakes in this sample are relatively large and apparently were struck from cores, instead of bifaces or trimmed flakes and chips.

Cortex Platform (241 specimens)

Cortex platform secondary flakes have been struck from unprepared cortex surfaces and have cortex platforms.

Single-Facet Platform (503 specimens)

Single-facet platform secondary flakes are produced by utilizing the single facet formed by the scar of a previous flake removal as a striking platform.

Multiple Large-Facet Platform (9 specimens)

Secondary flakes of this platform type are struck from platforms created, intentionaliy or unintentionally, by the previous removal of two or more large flakes.

Multiple Small-Facet Platform (3 specimens)

This platform type is prepared, intentionally or unintentionally, by the removal of several small flakes, usually struck from a bifacialiy worked edge.

Tertiary (414 specimens)

Tertiary flakes are removed from the decorticate portions of cores, flakes and bifaces, and exhibit no cortex.

Single-Facet Platform (318 specimens)

This form of tertiary flake, while of the same platform type as singlefacet platform secondary flakes, often terminates distally with a steep hinge fracture.

Multiple Large-Facet Platform (20 specimens)

These flakes are characterized by two or more large platform facets. 
Multiple Sma11-Facet Platform (76 specimens)

The multiple small-facet platforms of tertiary flakes often are

"lipped" (Shafer 1969:4), and have a somewhat arched appearance.

\section{Chips (948 specimens)}

Chips--broken flakes without platforms--constitute $40.7 \%$ of the entire 1 ithic sample, and can be divided into three groups based on the amount of cortex present.

Corticate (24 specimens)

This category includes those chips which retain cortex over their entire external surfaces and are fragments of primary or secondary flakes.

Partially Decorticate (447 specimens)

Fragments of secondary flakes comprise this category.

Decorticate (477 specimens)

Characterized by exterior surfaces which are devoid of cortex, decorticate chips are fragments of tertiary flakes and the decorticate portions of secondary flakes.

Modified Flakes and Chips (406 specimens; Fig. 5-8)

As mentioned previously, these artifacts (17.4\% of the entire lithic sample) have been included in the totals given in the foregoing classification of flakes and chips, and should not be counted twice.

Utilized Flakes and Chips (125 specimens; Fig. 5,a-h)

This category makes up $30.8 \%$ of the sample of artifacts classified as modified flakes and chips. An edge or edges of each specimen exhibits minute chipping or nibbling and occasional polish which may represent wear resulting from the use of the flake or chip as a tool. Because of 1 imitations of time, no microscopic examinations were made to determine whether flakes and chips that appear to be unmodified were in fact utilized as tools.

The utilized flake and chip sample includes 57 secondary flakes and 31 tertiary flakes (most of which have single-facet platforms), 16 partially decorticate chips, and 21 decorticate chips. Sizes range from a singlefacet platform secondary flake $7.1 \mathrm{~cm}$ long, $4.3 \mathrm{~cm}$ wide and $8.5 \mathrm{~mm}$ thick, to a decorticate chip $1.7 \mathrm{~cm}$ long, $1.0 \mathrm{~cm}$ wide and $2.0 \mathrm{~mm}$ thick.

At least 97 of the sample of 125 utilized flakes and chips exhibit signs of wear along lateral edges (in relation to medial axis of the flake) and 

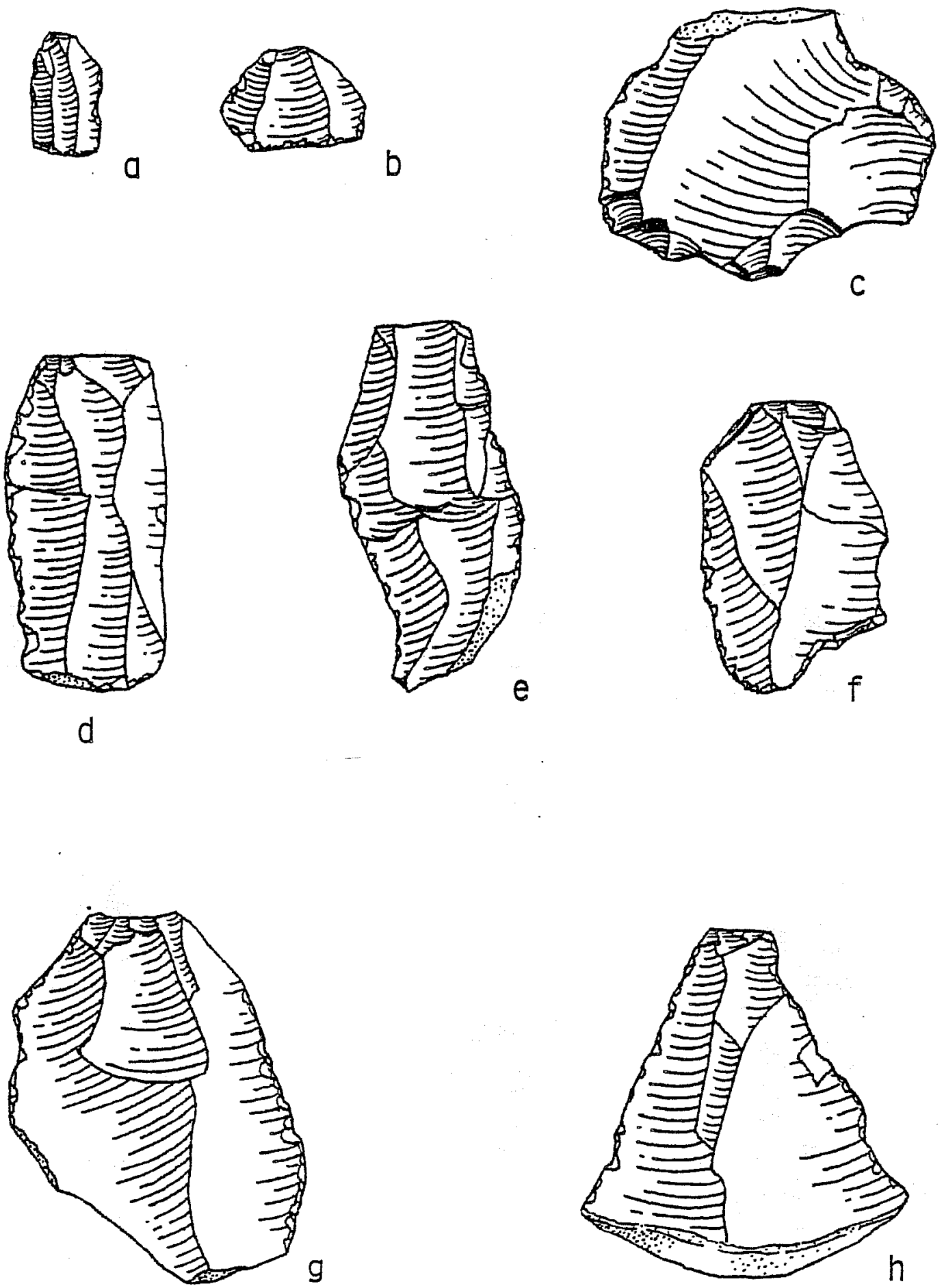

Figure 5. Utilized Flakes and Chips. a,b, $41 \mathrm{BX} 3 ; \mathrm{c}-\mathrm{h}, 41 \mathrm{BX} 5$. 

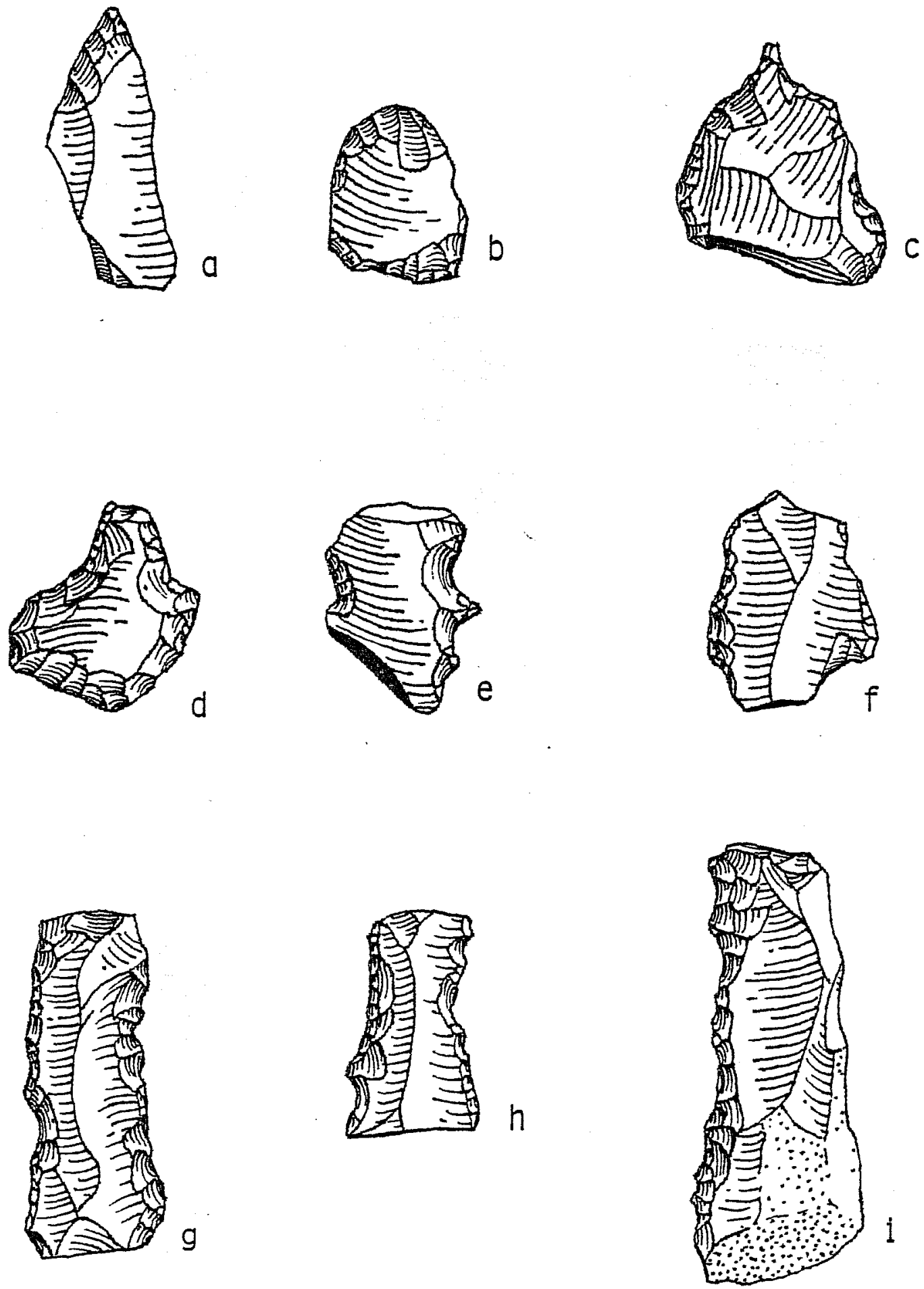

Figure 6. Trimmed Flakes and Chips. a,b, Group I (41 BX 5); $c-e$, Group II (c, d, 41 BX 5; e, 41 BX 12); f-i, Group III, Side(s) (f, 41 BX 3; g-i, $41 \mathrm{BX} 5$ ). 

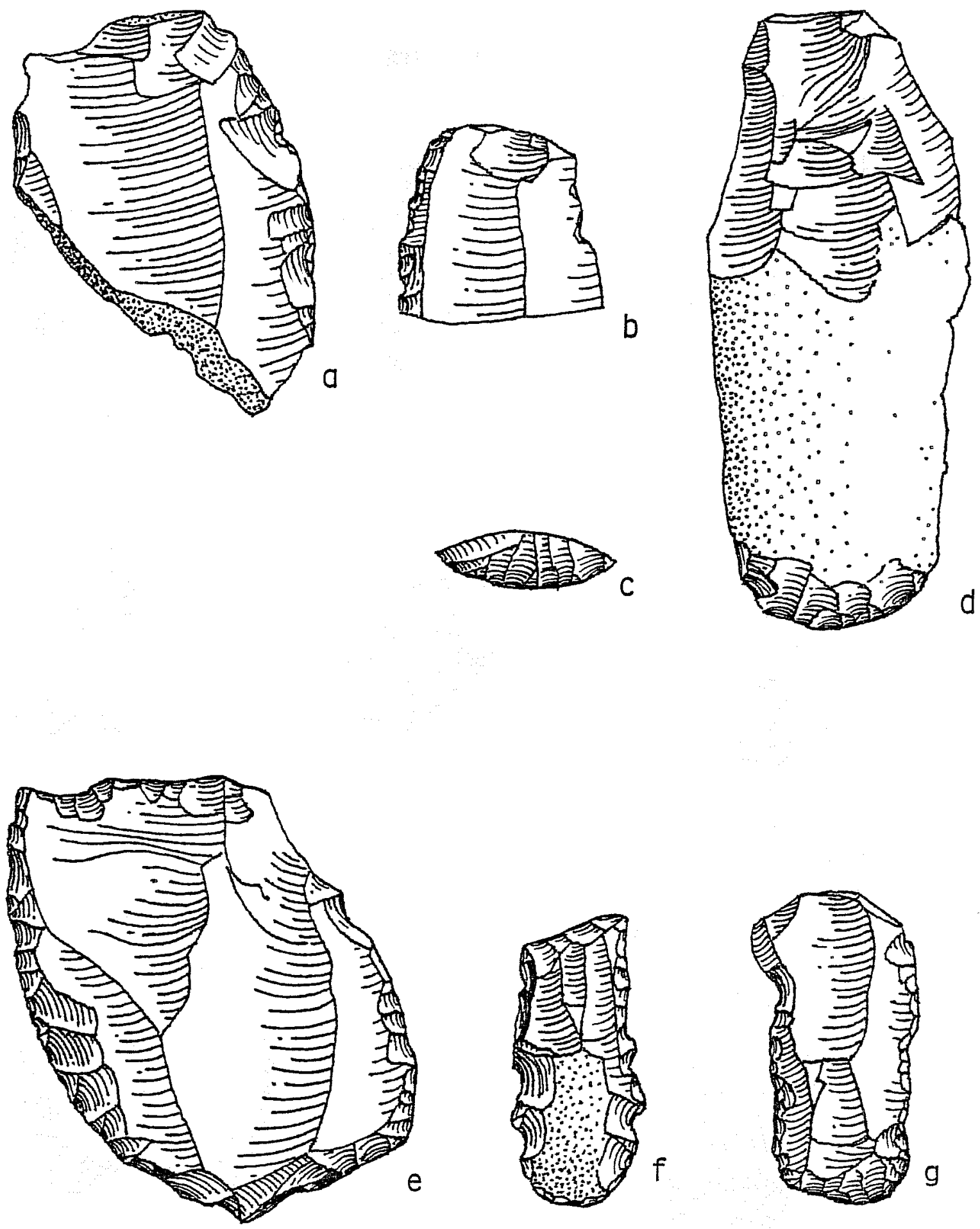

Figure 7. Trimmed Flakes and Chips, a,b, Group III, Side(s) (4I BX 5); $c, d$, Group III, End (41 BX 5); e-g, Group III, End and Side(s) (e,f, 41 $B X 5 ; g, 41 \mathrm{BX} 3)$. 

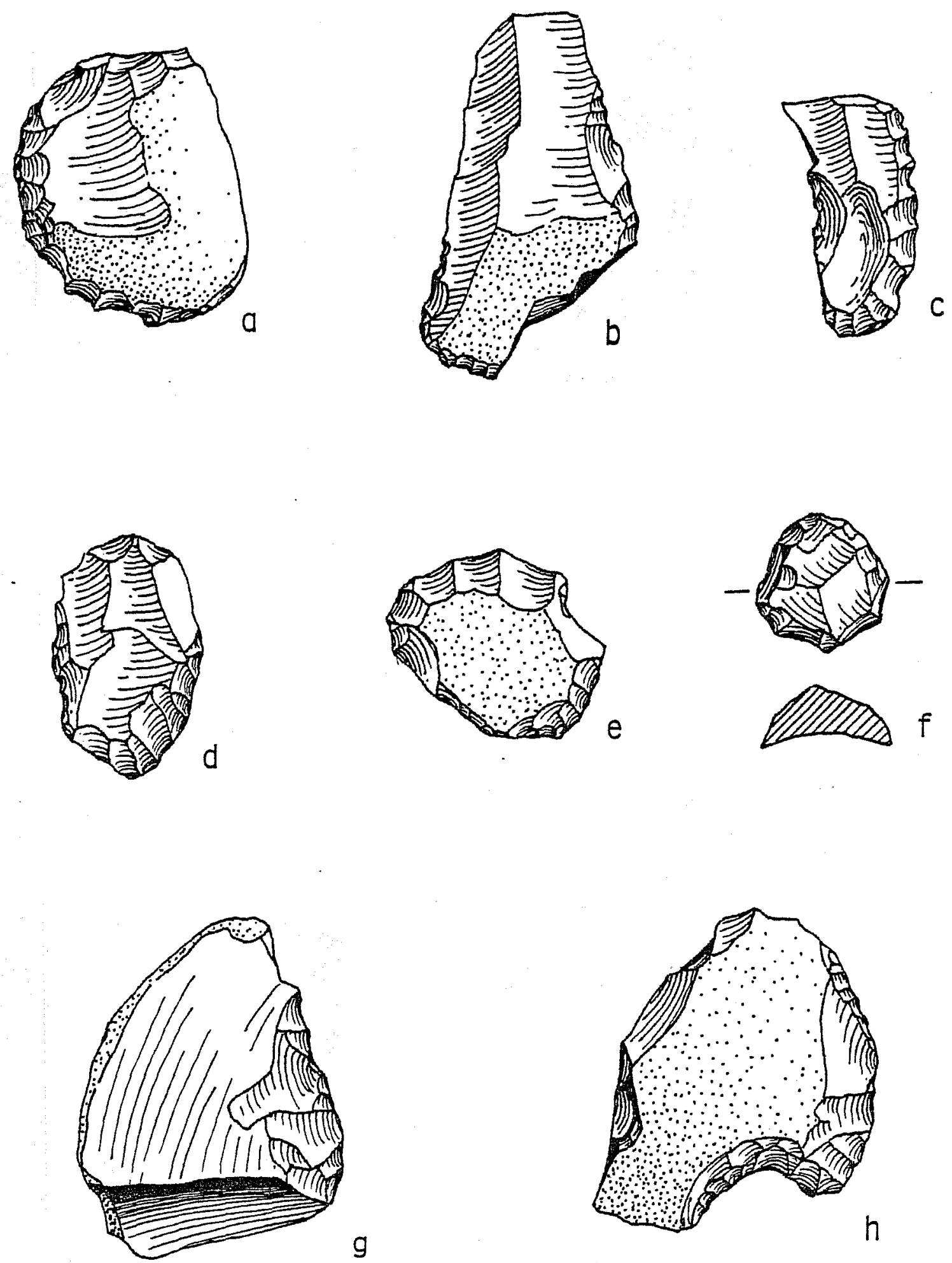

Figure 8. Thimmed Flakes and Chips. a-c, Group III, End and Side(s) (a,b, 41 BX 5; $c, 41$ BX 6); d-f, Group III, Ovoid or Rounded (d, $41 \mathrm{BX} 5$; e, $41 \mathrm{BX} 12 ; \mathrm{f}, 41 \mathrm{BX} 3$ ); g,h, Group III, Irregular or Indeterminable (41 BX 5). 
are similar to Group II I side trimmed flakes and chips. The distal ends (opposite the platform ends) of nine specimens appear to have been utilized and signs of wear are present on both the distal ends and the lateral edges of at least eight flakes and chips. Eleven irregulariy shaped specimens exhibit minute chipping and/or polish along sharp edges.

Trimmed Flakes and Chips (281 specimens; Fig. 6-8)

A trimmed flake or chip is characterized by edges which have been altered by the removal of small flakes, but only to the extent that most of the original interior and exterior surfaces of the flake can still be recognized. As such, trimming includes marginal shaping, retouch and/or thinning. The 281 specimens (69.2\% of the sample of modified flakes and chips) can be divided into three groups for descriptive purposes.

Group I (27 specimens; Fig. 6,a-b)

This category includes flakes and chips which bear scars of flake removals intended to thin certain parts of the original flake, rather than simply to shape or bevel the margins of the flake. A few specimens exhibit evidence of both thinning and beveling. Most are bifacially trimmed.

Most of the Group I artifacts are either subtriangular or roughiy pointed-ovate in outline. The shapes of some cannot be determined because of their fragmentary nature. Sizes range from a small fragment $0.9 \mathrm{~cm}$ long, $1.0 \mathrm{~cm}$ wide and $2.1 \mathrm{~mm}$ thick, to a large specimen $4.2 \mathrm{~cm}$ long, $3.4 \mathrm{~cm}$ wide and $6.9 \mathrm{~mm}$ thick. Most Group I trimed artifacts are similar in form to, and may represent initial stages in the production of, Group III thin bifaces.

Group II (7 specimens; Fig. 6,c-e)

At least one edge of each of the trimmed flakes in this group has a prominent point or beak, formed apparently by the intentional removal of small flakes. Some have been shaped by the removal of flakes from the exterior surfaces only. Others have been bifacially trimmed into shape.

This pointed form of trimmed flakes and chips often is referred to as "gravers" (see Skinner 1971:205, 222, 235, 253).

Group III (247 specimens; Fig. 6,f-i; Fig. 7,a-g; Fig. 8,a-h)

This group consists of various shapes and patterns of trimmed artifacts which can be divided into five general morphological sub-groups for descriptive purposes.

Side (90 specimens; Fig. 6,f-i; Fig. 7,a-b)

These have been trimmed along one or both edges, more or less parallel to the medial axis of the original flake. Trimmed edges 
are straight to convex and occasionally slightly concave. Most specimens have been unifacially trimmed along the exterior surface. Edge treatment varies from specimens which have been slightly trimmed along a portion of one edge, to some lone, narrow, bladelike flakes and chips (roughly parallel-sided and at least twice as long as wide) which exhibit signs of intensive trimming (and even battering) along lateral edges.

Most side trimmed specimens were fashioned from relatively large single-facet platform secondary and tertiary flakes. Sizes range from a broad flat corticate chip $7.6 \mathrm{~cm}$ long, $6.0 \mathrm{~cm}$ wide and $15.2 \mathrm{~mm}$ thick, to a decorticate chip $2.0 \mathrm{~cm}$ long, $2.2 \mathrm{~cm}$ wide and $6.2 \mathrm{~mm}$ thick.

End (4 specimens; Fig. $7, c-d$ )

These are flakes and chips which have been trimmed only along the distal end, more or less perpendicular to the medial axis of the original flake. Distal ends are straight to convex. Three specimens are unifacially trimmed on the exterior surface.

End and Side (55 specimens; Fig. 7,e-g; Fig. 8,a-c)

These artifacts have been trimmed along one or both edges, more or less parallel to the medial axis, as well as along the distal end, perpendicular to the medial axis of the original flake. Lateral edges are straight to slightly convex. Except for a few specimens with irregularly trimmed ends, the tools have straight to convex distal ends. Most end and side trimmed artifacts have been unifacially trimmed on the exterior surface. Sizes range from a large trimmed partially decorticate chip $9.1 \mathrm{~cm}$ long, $7.6 \mathrm{~cm}$ wide and $27.3 \mathrm{~mm}$ thick, to a trimmed single-facet platform tertiary flake $3.1 \mathrm{~cm}$ long, $2.6 \mathrm{~cm}$ wide and $8.5 \mathrm{~mm}$ thick.

The sample of 55 end and side trimmed flakes and chips includes 8 cortex platform and 27 single-facet platform tertiary flakes, 10 partially decorticate chips (distal portions of trimmed secondary flakes) and 5 decorticate chips (distal portions of trimmed secondary and/or tertiary flakes). Most of these artifacts are similar to forms referred to as "end scrapers" reported from prehistoric archaeological sites (see Skinner 1971:183, 205, 252; Hester 1971:95-97).

Ovoid or Rounded (11 specimens; Fig. 8,d-f)

This category includes flakes and chips which have been trimmed into a rounded or ovoid outline shape. Generally unifacially trimmed on exterior surfaces, 3 are partially decorticate chips, 7 are decorticate chips and one is a thick cortex platform secondary flake (from the San Jose collection) which may have served as a core for the production of small flakes. 
Irregular or Indeterminable (87 specimens; Fig, 8,g-h)

This category consists of a miscellaneous group of flakes and chips which have been trimmed in various irregular patterns, and specimens too fragmentary to assign to specific morphological subgroups. The sample includes 7 cortex platform and 10 single-facet platform secondary flakes, 8 single-facet platform tertiary flakes, 24 partially decorticate chips and 38 decorticate chips.

Bifaces (68 specimens; Figs. 9,10)

This major category consists of $3.0 \%$ of the entire 1ithic sample. Each specimen exhibits bifacial flaking apparently intended to reduce a cobble, core or flake to a functional shape. Most bifaces appear to have been formed from flakes, although in some cases bifacial flaking has removed all evidence of the original flake surfaces. Bifaces are divided into two groups based on thickness. Further subdivision is based on form.

Thick (3 specimens; Fig. 9,a-b)

These artifacts ( $4.4 \%$ of the biface sample) include two bifaces and a large biface fragment which are thicker than $1.3 \mathrm{~cm}$. All three decorticate thick bifaces were recovered from Mission Concepción. One, $4.9 \mathrm{~cm}$ long, $4.5 \mathrm{~cm}$ wide and $20.0 \mathrm{~mm}$ thick, has been burned. Another, $4.7 \mathrm{~cm}$ long, $3.9 \mathrm{~cm}$ wide and $16.0 \mathrm{~mm}$ thick, shows signs of battering and grinding along its broken and unbroken edges.

The remaining thick biface is triangular in shape, and plano-convex in cross section (Fig. 9,a). The dorsal or convex surface is highest a short distance from the steeply beveled end or base. Cracked and pitted from having been burned, this tool $(5.8 \mathrm{~cm}$ long, $3.7 \mathrm{~cm}$ wide and $15.9 \mathrm{~mm}$ thick) is similar to Clear Fork artifacts commonly reported from prehistoric archaeological sites in Texas (Hester, GiTbow and Albee 1973).

Thin (65 specimens; Fig. 9,c-f; Fig. 10,a-1)

Thin bifaces (95.6\% of the biface sample) probably represent products and byproducts of the final stages of biface tool production. They appear to reflect predetermined shaping rather than the shapes of the original cobbles, cores or flakes from which they were manufactured. Most specimens probably were fashioned from flakes.

Thin bifaces are less than $1.3 \mathrm{~cm}$ thick and retain little or no cortex.

Group I (12 specimens; Fig. 9,c-f)

This category includes 12 fragments of bifacially thinned artifacts which range in thickness from approximately $4.1 \mathrm{~mm}$ to $9.6 \mathrm{~mm}$. Nine specimens, two of which have been burned, are fragments of the medial portions of roughly parallel-sided and pointed forms, lenticular in cross section, which appear to be fragments of dart point forms frequently reported from 

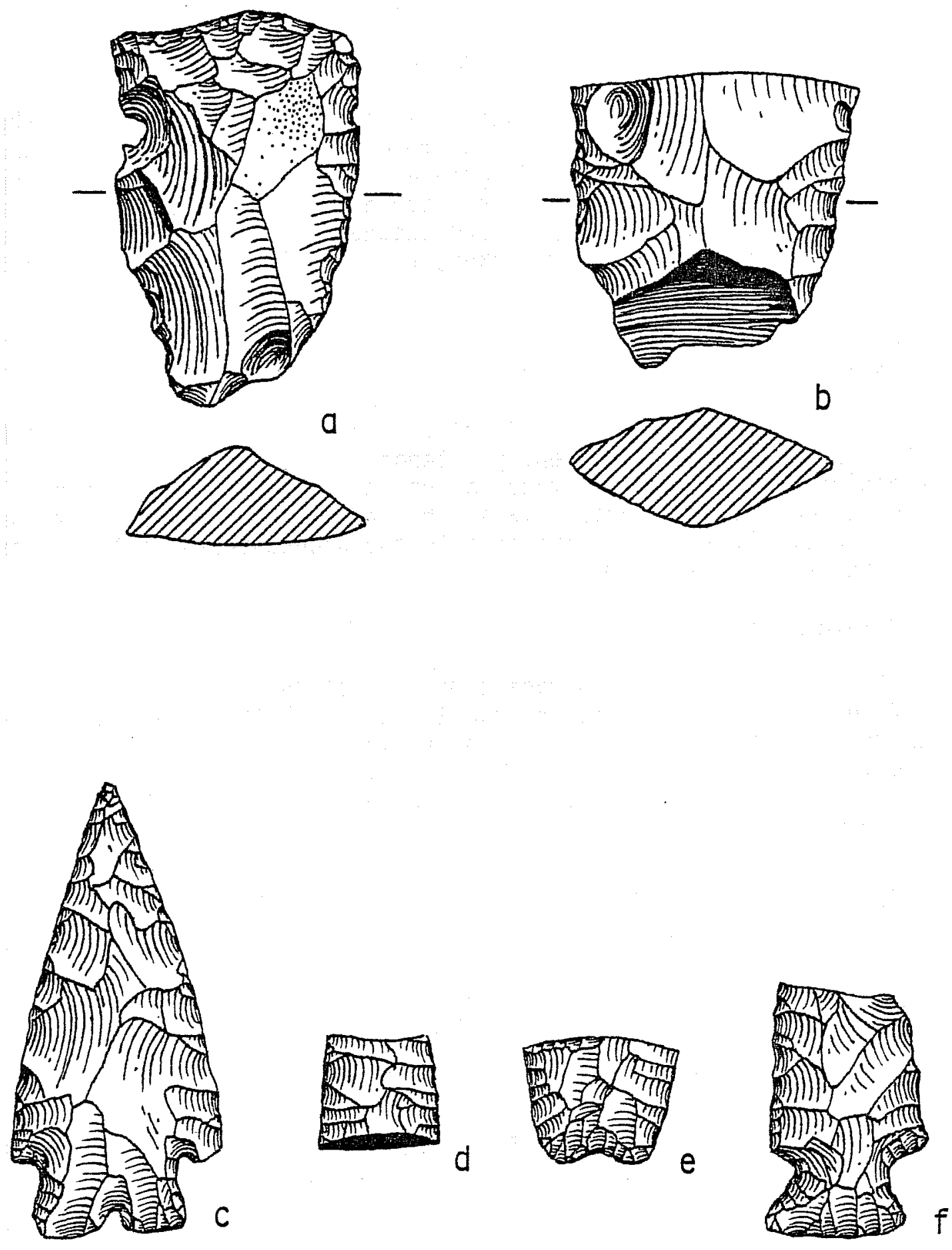

Figure 9. Bifaces. $a, b$, thick bifaces (41 BX 12); $c-f$, thin bifaces, Group I (c, 41 BX 5; d-f, 41 BX 12). 

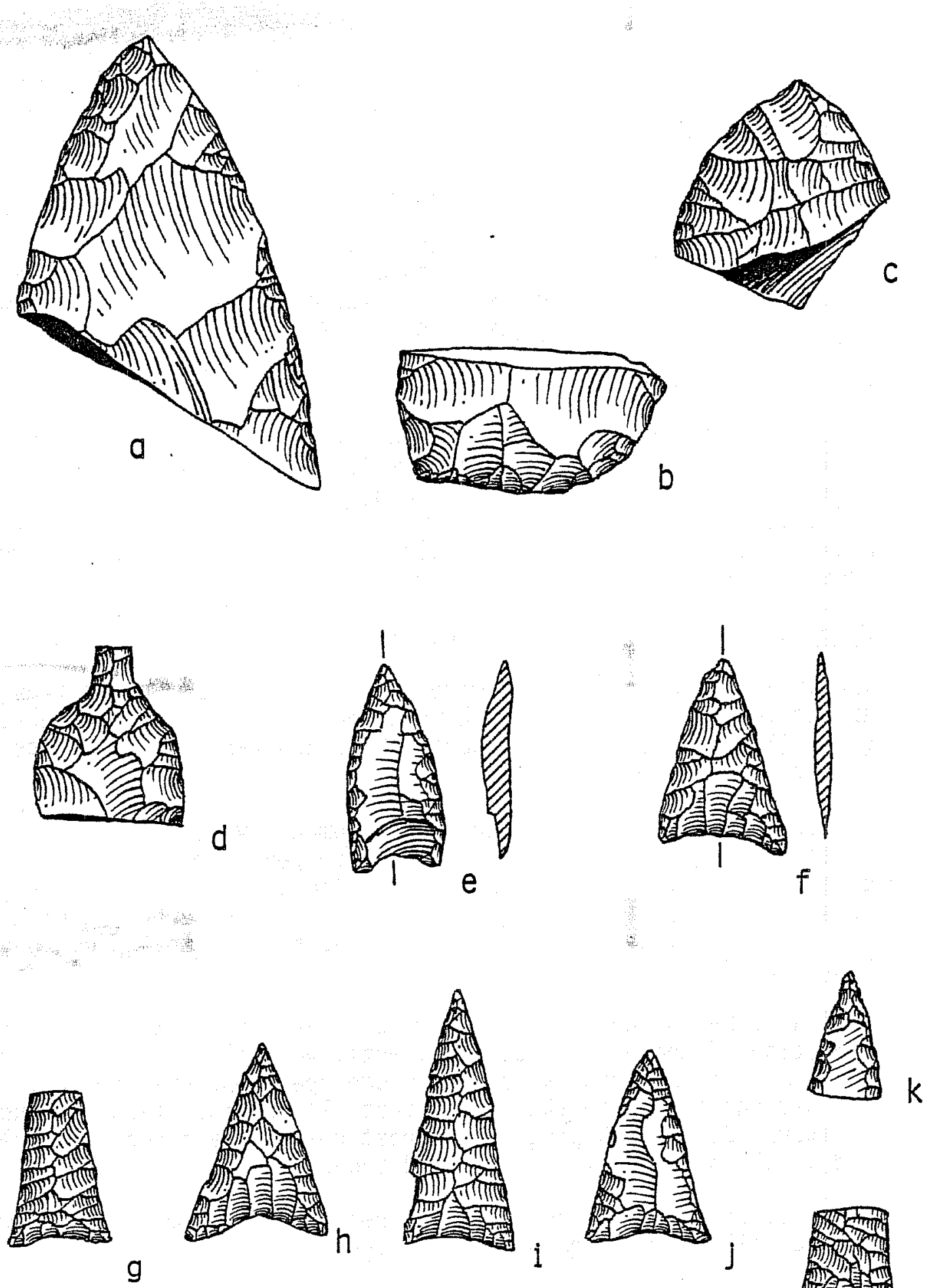

Figure 10. Bifaces. a-c, thin bifaces, Group II (a, 41 BX $3 ; b$, 41 BX 12; c, 41 BX 5); d, th in bifaces, Group III (4I BX 12); e-T, thin bifaces, Group IV (e-i, 41 BX 5; j, 41 BX 6; k [glass], 1, $41 \mathrm{BX} 3)$. 
prehistoric sites. The three remaining Group I thin bifaces are basal fragments of stemmed thin bifaces--forms considered diagnostic of the prehistoric Archaic Period occupation of central and south Texas (Suhm, Krieger and Jelks 1954).

Group II (4 specimens; Fig. 10,a-c)

These artifacts range in thickness from $5.4 \mathrm{~mm}$ to $8.0 \mathrm{~mm}$, and in width from $3.1 \mathrm{~cm}$ to $5.2 \mathrm{~cm}$. Three fragments appear to represent large subtriangular or pointed-ovate thin bifaces. Similar in shape, the other Group II specimen is subtriangular, $4.1 \mathrm{~cm}$ wide, and $7.5 \mathrm{~mm}$ thick.

Group III (1 specimen; Fig. 10,d)

This fragmentary thin biface retains small portions of the interior and exterior surfaces of the flake from which it was made. Bifacially thinned or trimmed along two sides, it has an ovate base $2.5 \mathrm{~cm}$ wide and $8.2 \mathrm{~mm}$ thick, and a long, narrow projection or stem $6.5 \mathrm{~mm}$ wide and $4.3 \mathrm{~mm}$ thick. This broken projection exhibits visible signs of grinding or wear which may have resulted from its use as a perforator or boring implement.

Group IV (48 specimens; Fig. $10, e-1$ )

The artifacts of this group were manufactured from thin flakes of chert except for two specimens which were knapped from sherds of green bottle glass (Fig. $10, k$ ). All are decorticate and range in thickness from 1.6 to $4.3 \mathrm{~mm}$.

All appear to be complete forms or fragmentary portions of triangular and subtriangular, bifacially thinned and shaped forms with straight, slightly concave, or slightly indented bases. Sides are most often slightly convex or straight. The sides of some specimens are somewhat recurved. Complete or nearly complete Group IV thin bifaces are 2.0 to $4.0 \mathrm{~cm}$ long and 1.2 to $2.2 \mathrm{~cm}$ wide.

Indicated by the number and length of flake scars, the extent of facial reduction of these artifacts apparently was related to the thickness and curvature of the original flake. Some specimens are completely bifacially thinned and shaped to the extent that all original flake surfaces have been obliterated. The shaping of the rest reflects a concern for planar symmetry and basal thinning of the finished product.

Group IV thin bifaces commoniy are referred to as mission arrow points (Hester 1977 terms them Guerrero points).

Gunflints and Strike-0-Lites (40 specimens; Fig. 11,a-f)

Because technological function can be associated reliably with these tools (1.7\% of the entire lithic sample), and because many of them are of European origin, gunflints and strike-o-lites, and a subsequently defined category, possible gunflints, are assigned to separate, relatively distinct categories of chipped stone. 

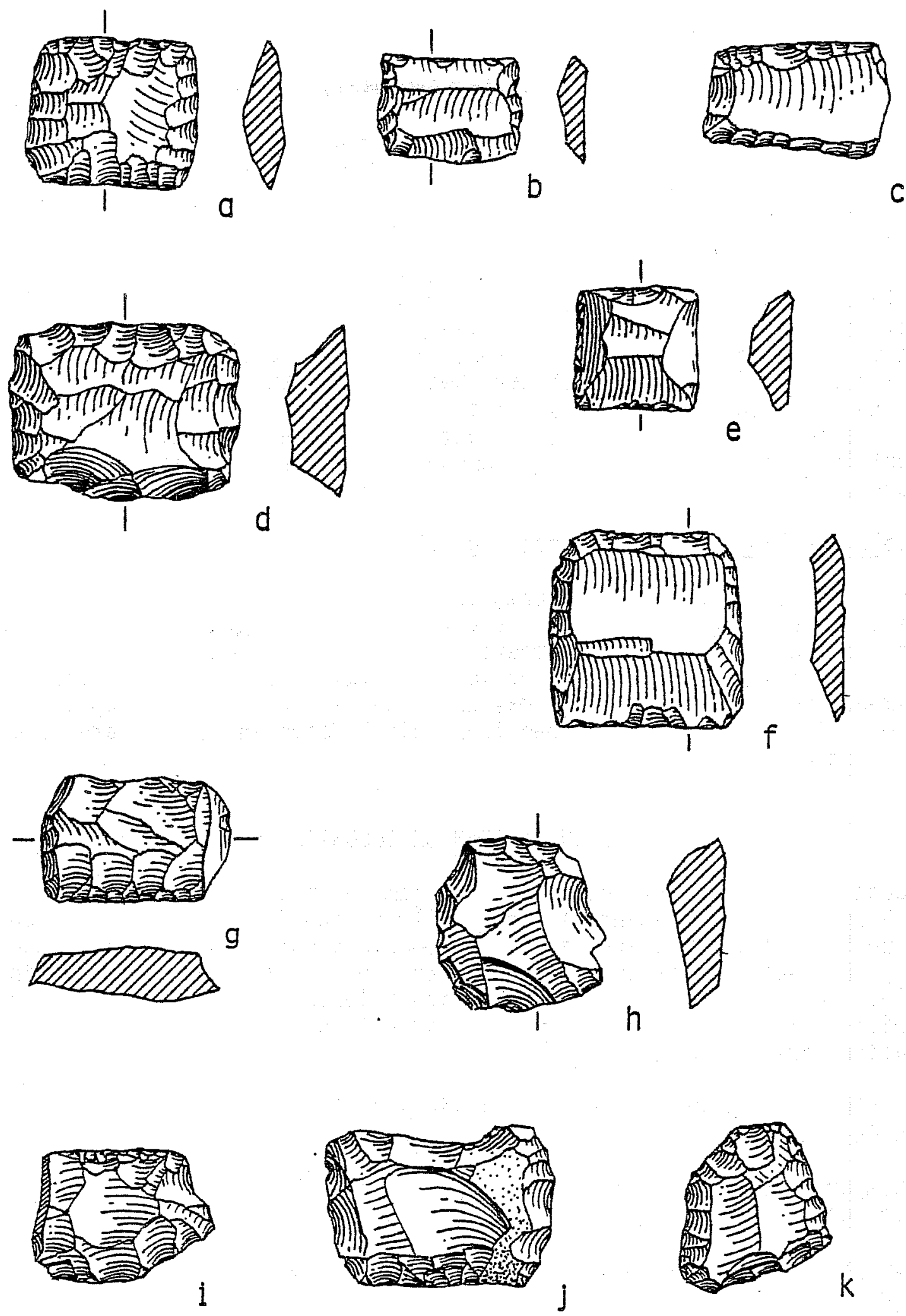

Figure 11. Gunflints and Strike-0-Lites and Possible Gunflints. a-f, gunflints and strike-o-lites (a-e, $41 \mathrm{BX} 5$; f, $41 \mathrm{BX} 12$; e, $f$, European); g-k, possible gunflints (g, $41 \mathrm{BX} 12 ; h-k, 41 \mathrm{BX} 5$ ). 
At least three different types of 1 ithic resource material are represented by the gunflints: dark gray or black (4 specimens), honey-colored ( 1 specimen), and what appears to be locally available chert (35 specimens). The dark grey and honey-colored gunflints probably are of eighteenth century English and French origin (Smith 1960; Hamilton 1960) and are of musket, carbine and pistol sizes. Some of these European gunflints (Fig. 11, e-f) appear to have been trimmed from blades. Others are spall or flake gunflints.

Generally similar in size and outline shape to the European specimens, the 35 gunflints of apparently local material vary somewhat in thickness and in chipping treatment (Fig. 11,a-d). Four relatively large rectanguloid specimens actually may have functioned as strike-o-lites. Eight are completely bifacial, while the rest are flakes and chips which have been thinned and/or trimmed to varying degrees in order to produce the desired functional shape. Some appear to have been made from blade-like flakes. Most are bifacially trimmed. Three of the 35 gunflints of chert retain small amounts of cortex on exterior and/or platform surfaces.

Possible Gunflints ( 31 specimens; Fig. 11,g-k)

Al though not as consistent in form, the rectanguloid and subrectanguloid artifacts of this category (1.3\% of the entire lithic sample) are similar in size, shape and flaking treatment to previously described gunflints. Most of the 31 possible gunflints appear to be of locally available chert. Two fragmentary specimens are honey-colored and may have been imported from Europe. Some of the possible gunflints are shaped from thin bifaces and others are trimmed flakes and chips.

\section{IDENTIFICATION OF SPANISH COLONIAL PERIOD LITHICS}

Although the majority if not all of the sample of 2,329 chipped stone artifacts are thought to be representative generally of the Spanish Colonial occupation of four San Antonio mission sites, it seems appropriate to consider the possibility that some prehistoric period chipped stone might be contained in the sample. In an attempt to isolate Spanish Colonial Period lithic cultural material from possible prehistoric contamination, the following series of suboperations are pursued:

1) A study of the chronological affiliation of deposits excavated within each site.

2) Comparisons of morphologically defined Tithic categories between sites (or collections).

3) Comparisons of 1ithic forms of the San Antonio mission sample with chipped stone reported from archaeological investigations at various Spanish Colonial sites in Texas and northern Mexico.

Following this appraisal, a summary of diagnostic, or distinctive, probable and possible Spanish Colonial Period forms of chipped stone is presented. 
Chronological Association Within Each Site

of the five collections studied, the sample of chipped stone from Mission Concepciôn (Scurlock and Fox 1977) seems to have the greatest possibilities for contamination by prehistoric lithics. Concepción, like the other sampled mission sites, is located a relatively short distance from a reliable water source (the San Antonio River channel), and therefore may have had potential as a suitable occupational area for prehistoric inhabitants. Much of the Concepción sample was recovered from test pits located within or in direct association with structures, midden deposits and other features which can be affiliated reliably with the occupation of the mission. However, some excavated materials, especially lithics recovered from test pits in the west compound area, could be representative of the prehistoric period.

The two collections from Mission San Josê (Schuetz 1970; Clark 1978) were recovered from deposits excavated from various places, both within and outside the compound area of the site. Although it is conceivable that some of the lithic specimens sampled could be representative of prehistoric occupations, the fill from which chipped stone was recovered contained Spanish Colonial Period and later (American) artifacts of ceramics, metal and glass. The chipped stone sample from Mission San Antonio de Valero also was found in association with eighteenth, nineteenth and some twentieth century cultural material (Schuetz 1973).

The 1,085 lithic specimens which comprise the collection from Mission San Juan Capistrano probably all can be affiliated reliably with the Spanish Colonial Period. Well over $90 \%$ of the deposits from which the lithic collection was recovered was fill excavated from within mission structures. Other deposits were excavated from one part of the compound area (Schuetz 1969: map following page 5). A11 lithic material was found in association with Spanish Colonial Period and later ceramic, metal and glass artifacts.

\section{Comparisons Between Collections}

Table 2 presents the provenience of all chipped stone specimens analyzed from each site. Because the information concerning the exact horizontal and vertical recovery location of many artifacts in two collections has been lost or could not be determined, the provenience of specimens within each site cannot be presented in this study.

A variety of morphologically defined lithic categories is represented in a11 five analyzed collections. Many of these, such as kinds of modified and unmodified flakes and chips, might be expected to occur at prehistoric as well as historic occupation sites where lithic tool production was carried on. However, probable Spanish Colonial Period chronological affiliation can be suggested for gunflints and strike-o-lites, and possible gunflints, and for the common occurrence of Group III side trimmed flakes and chips.

Considering categories represented in three or more collections, the only chipped stone forms which do not occur this frequently are core-tools, multiple small-facet platform secondary and multiple large-facet platform tertiary flakes, 
TABLE 2. PROVENIENCE OF THE STUDY SAMPLE

\begin{tabular}{|c|c|c|c|c|c|c|}
\hline \multirow[b]{2}{*}{ Morphological Category } & \multicolumn{6}{|c|}{ Mission Collection } \\
\hline & 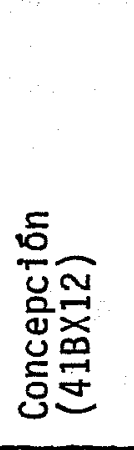 & 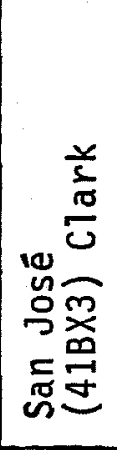 &  & 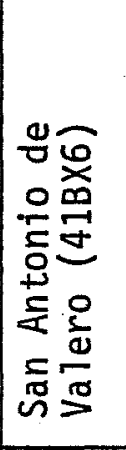 & 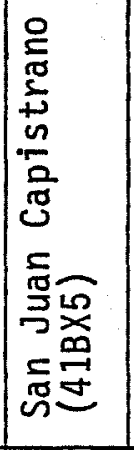 & $\frac{n}{\pi}$ \\
\hline CORES & 9 & 9 & 2 & 0 & 21 & 41 \\
\hline Cortex Platform & 3 & 5. & 0 & 0 & 4 & 12 \\
\hline Decorticate Platform & 6 & 4 & 2 & 0 & 17 & 29 \\
\hline CORE-TOOLS & 5 & 0 & 0 & 0 & 2 & 7 \\
\hline Total & 14 & 9 & 2 & 0 & 23 & 48 \\
\hline FLAKES AND CHIPS & 910 & 109 & 81 & 48 & 994 & 2142 \\
\hline Flakes & 499 & 38 & 44 & 23 & 590 & 1194 \\
\hline Primary & 16 & 1 & 0 & 0 & 7 & 24 \\
\hline Secondary & 283 & 25 & 24 & 17 & 407 & 756 \\
\hline Cortex Platform & 94 & 15 & 8 & 8 & 116 & 241 \\
\hline Single-Facet Platform & 184 & 10 & 15 & 9 & 285 & 503 \\
\hline Multiple Large-Facet & 4 & 0 & 1 & 0 & 4 & 9 \\
\hline Multiple Sma11-Facet & 1 & 0 & 0 & 0 & 2 & 3 \\
\hline Tertiary & 200 & 12 & 20 & 6 & 176 & 414 \\
\hline Single-Facet Platform & 141 & 10 & 18 & 6 & 143 & 318 \\
\hline Multiple Large-Facet & 10 & 0 & 0 & 0 & 10 & 20 \\
\hline Multiple Smal1-Facet & 49 & 2 & 2 & 0 & 23 & 76 \\
\hline Chips & 411 & 71 & 37 & 25 & 404 & 948 \\
\hline Corticate & 14 & 4 & 0 & 1 & 5 & 24 \\
\hline Partially Decorticate & 175 & 37 & 18 & 9 & 208 & 447 \\
\hline Decorticate & 222 & 30 & 19 & 15 & 191 & 477 \\
\hline Total & 910 & 109 & 81 & 48 & 994 & 2142 \\
\hline
\end{tabular}


TABLE 2. (Continued)

Morphological Category

\begin{tabular}{|c|c|c|c|c|c|}
\hline \multicolumn{6}{|c|}{ Mission Collection } \\
\hline 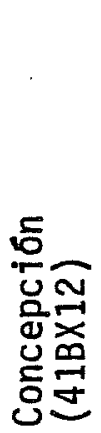 & 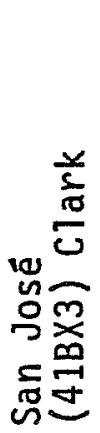 &  & 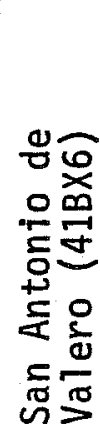 & 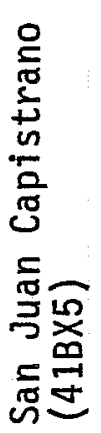 & $\begin{array}{l}\frac{\infty}{\pi} \\
\stackrel{0}{0}\end{array}$ \\
\hline 93 & 7 & 44 & 25 & 237 & 406 \\
\hline 16 & 3 & 23 & 8 & 75 & 125 \\
\hline 77 & 4 & 21 & 17 & 162 & 281 \\
\hline 18 & 0 & 0 & 0 & 9 & 27 \\
\hline 3 & 0 & 1 & 0 & 3 & 7 \\
\hline 56 & 4 & 20 & 17 & 150 & 247 \\
\hline 20 & 2 & 4 & 7 & 57 & 90 \\
\hline 1 & 0 & 0 & 0 & 3 & 4 \\
\hline 18 & 0 & 1 & 4 & 32 & 55 \\
\hline 2 & 1 & 1 & 0 & 7 & 11 \\
\hline 15 & 1 & 14 & 6 & 51 & 87 \\
\hline 93 & 7 & 44 & 25 & 237 & 406 \\
\hline
\end{tabular}

BIFACES

Thick

Thin

Group I

Group II

Group III

Group IV

\begin{tabular}{l|r|r|r|r|r|r}
\hline Total & 34 & 4 & 5 & 1 & 24 & 68 \\
GUNFLINTS & 7 & 1 & 3 & 1 & 28 & 40 \\
POSSIBLE GUNFLINTS & 4 & 3 & 5 & 3 & 16 & 31 \\
\hline Total & 11 & 4 & 8 & 4 & 44 & 71 \\
Grand Total & 969 & 126 & 96 & 53 & 1085 & 2329 \\
\hline
\end{tabular}

* Modified Flakes and Chips have been abstracted from the sample of all Flakes and Chips and, therefore, should not be counted twice. 
Group I (thinned as well as shaped) trimmed flakes and chips, Group III end trimmed flakes and chips, thick bifaces, and Group III (perforator) thin bifaces. The lack of representation of some of these categories might be explained by the relatively small total numbers of specimens contained in the collections from Missions San José and San Antonio de Valero. In other words, examples of these forms might be encountered in samples comparable in size to those from Mission Concepción.

Although the relatively common occurrence of most categories in collections from the four different sites gives weight to the argument that most, if not all, of the 1ithic sample is representative of the Spanish Colonial Period, there are those forms which do not occur in all five collections and therefore are somewhat more questionable as to chronological affiliation. Important among these morphological categories are core-tools, Group I (thinned as well as shaped) trimmed flakes and chips, Group III end trimmed flakes and chips, thick bifaces, and thin biface Groups I-ITI.

Group I trimmed flakes and chips appear to be representative of initial stages in the production of Group IV thin bifaces (mission arrow points), and probably can be assigned confidently to the Spanish Colonial mission occupation. Group III end trimmed flakes and chips appear to be broken ends from, or perhaps initial stages in the production of, Group III end and side trimmed flakes and chips.

Still of especially questionable chronological affiliation are core-tools, Group II (pointed) trimmed flakes and chips, thick bifaces, and thin biface Groups I-III.

\section{Comparisons With Other Collections}

The chronological affiliation of various chipped stone categories defined for the mission sample can be considered further by investigating whether or not they are represented in other collections from Spanish Colonial Period sites in Texas and northern Mexico. Information concerning eight comparative collections was obtained from published reports on different archaeological investigations. Three of these reports deal with San Antonio mission collections which were not analyzed as part of the study sample (Fox 1970:45-46, Fig. 21; Greer 1967:63-66, 86-89, Figs. 24 and 29; Schuetz 1974:40-42, Fig. 16). Four reports contain information concerning chipped stone from Spanish Colonial sites in central Texas (Gilmore 1969:116-120, Fig. 13; Gilmore 1967:23-24, Fig. 7), coastal Texas (Tunnell and Ambler 1967:92-97, Fig. 15), and southern Texas (Gilmore 1974:99-105, 107-109, Figs. 32,33). Another report deals with lithics recovered during recent work at San Bernardo Mission in the vicinity of Guerrero, Coahuila, Mexico (Hester 1976a:23-26, Figs.-4,5).

Information from a ninth collection was obtained from a cursory inspection of chipped stone artifacts recovered during investigations in 1971 of the convento area at San Antonio's Mission San Juan Capistrano (41 BX 5) by Mardith K. Schuetz. No documentation of that investigation has been published. The collection is stored at the Center for Archaeological Research, The University of Texas at San Antonio. 
Table 3 presents the morphological categories defined for the study sample as they occur in the nine comparative collections. As might be expected, collections from investigations at Missions San Juan and San Antonio de Valero compare more closely with the study sample than do collections from Spanish Colonial sites located outside the San Antonio area. It is interesting that at least 16 of a possible 23 morphological categories are represented by lithics reported from San Bernardo Mission in northern Mexico.

General chipped stone categories such as flakes and chips, trimmed flakes and chips, and thin bifaces are represented in most collections. Such forms might be expected to occur at prehistoric and historic sites where lithic tools were produced. The lack of representation of more specifically defined morphological categories in some collections could reflect differing lithic technologies at mission sites in different areas, as well as variation in interests and methods of analysis and reporting employed by the different investigators.

In any case, the relatively common occurrence of Group III side, and end and side trimmed flakes and chips may reflect an emphasis on flake-tool production at mission sites. This suggestion a Tready has been made by Schuetz (1969:70-71) and Hester (1975b:25).

Gunflints and strike-o-lites, and possible gunflints, considered to be representative of the Spanish Colonial Period, occur in various comparative collections. Group IV thin bifaces (mission arrow points) also occur commoniy.

Still of questionable chronological affiliation are core-tools, Group II (pointed) trimmed flakes and chips, thick bifaces, and thin biface Groups I-III. It seems significant that each of these categories is represented in at least one collection from sites located outside the San Antonio area, even though it is possible that there were prehistoric occupations at these sites.

Chopper-like core-tools occur in collections from San Antonio area sites and from Mission Rosario near Goliad in south Texas. Similar chipped stone implements are found commonly at prehistoric sites in south and south-central Texas (Mallouf, Fox and Briggs 1973:64; Fox et al. 1974:26; Lynn, Fox and O'Malley 1977; Hester 1971:86; and others). Group II (pointed) trimmed flakes and chips also occur frequentiy at prehistoric sites in Texas (Fox et al. 1974:34; Skinner 1971:205,222,235,253; Hester 1971:94).

A most intriguing problem concerns the occurrence of thick bifaces and thin biface Groups I-III, forms usually associated with prehistoric occupations, at Spanish Colonial sites in Texas and northern Mexico. Group I and Group II thin bifaces, complete and fragmentary forms of dart points and other large thin knifelike tools, occur in four comparative collections (Table 3). Many of the fragmentary specimens in the study sample are rectanguloid in shape and may have been used as gunflints or other tools. Hester (1975b:24-25) has considered the problem of the chronological affiliation of prehistoric-looking thin bifaces from Spanish Colonial sites:

It is difficult to explain the presence of these specimens in the historic midden deposits, as it is assumed that the bow and arrow had completely replaced the spear thrower by this time. However, Suhm, Krieger, and Jelks (1954:138) report the 


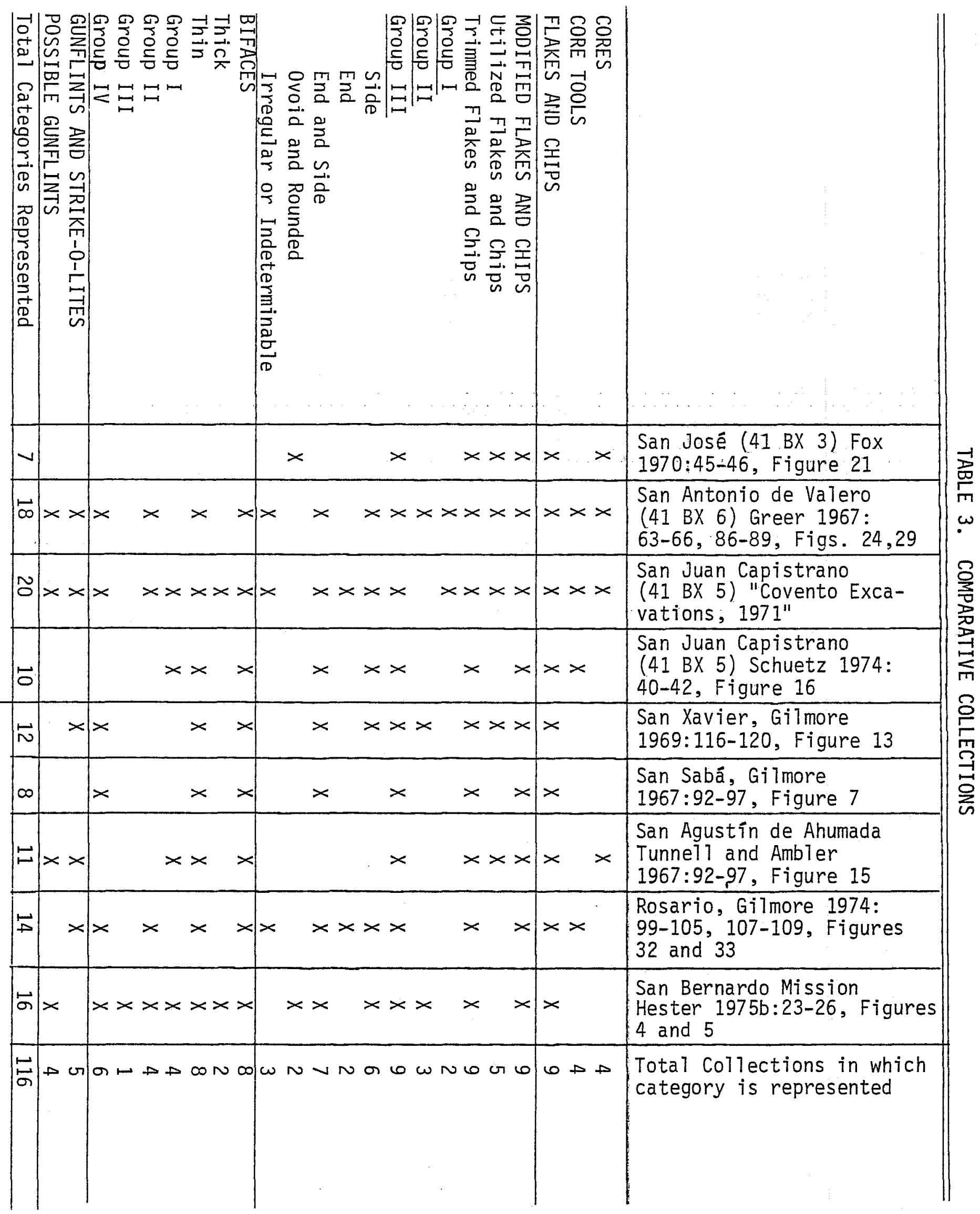


occurrence of dart points in Spanish Colonial contexts in the Falcon Reservoir along the lower Rio Grande, and occasional dart points are found at Texas missions (cf. Schuetz 1969). Perhaps the larger specimens were not dart points at a11, but functioned as knives during the historic era; or, it is possible that smaller "dart points" were actually employed as arrow-tips (cf. Hester and Hi11 1973:40-41). There is also the very slight chance that the spear thrower was still in use on a limited basis; however, this is not recorded in Spanish accounts and does not seem likely. Some of the temporally-diagnostic forms ... . may have been picked up by the mission Indians from eroded prehistoric sites . . . Such ancient specimens might have been regarded as curios, or more probably, as tools to be re-used. An interesting example of the re-use of prehistoric lithics by historic flint-knappers is reported by Goodwin and Basso (1971:231). They describe the practice of western Apaches who would go around to ruins and pick up pieces of flint to be utilized in arrow point manufacture.

Summary of Spanish Colonial Period Chipped Stone

From the foregoing appraisal of the chronological affiliation of lithic artifacts from Spanish Colonial sites in San Antonio and contemporaneous sites in Texas and northern Mexico, the entire San Antonio mission sample cannot be affiliated confidently with the Spanish Colonial Period (eighteenth century). Instead, a summary of probable and possible mission lithic forms is presented in Table 4.

\section{INTERPRETATION OF TECHNOLOGY}

Despite the possibility that the sample of chipped stone from four San Antonio missions might contain some prehistoric lithic material, the sample, consisting of 2,329 specimens, is thought to be large enough to be representative of general technological patterns involved in the production of chipped stone tools during Spanish Colonial mission occupations. This contention seems more reasonable if it can be assumed that pre-mission lithic forms were re-used or continued to be made by the eighteenth century mission occupants.

Except for the European-made gunflints, and the Group IV thin biface fragments made from bottle glass, neither allochthonous stone nor other convincing evidence of trade or transport of 7ithic resource materials is exhibited by the mission sample. Most of the assemblage apparently was produced from locally available chert cobbles.

The presence of a number of large cores which have been only partially reduced, and the frequency of occurrence of primary flakes in the sample, suggest that a variety of chert cobbles were carried into the missions, presumably from relatively accessible resource areas containing gravels of suitable quality 7 ithic material. However, evidence of bipolar flaking, a flintworking technique thought 
TABLE 4. PROBABLE AND POSSIBLE SPANISH COLONIAL CHIPPED STONE

\begin{tabular}{|c|c|c|}
\hline \multirow[b]{2}{*}{ Morphological Category } & \multicolumn{2}{|c|}{$\begin{array}{l}\text { Identification } \\
\text { With the } \\
\text { Spanish Colonial } \\
\text { Period }\end{array}$} \\
\hline & Probabie & Possible \\
\hline CORES & $x$ & \\
\hline Cortex Platform & $x$ & \\
\hline Decorticate Platform & $x$ & \\
\hline CORE-TOOLS & & $x$ \\
\hline FLAKES AND CHIPS & $x$ & \\
\hline MODIFIED FLAKES AND CHIPS & $x$ & \\
\hline Utilized Flakes and Chips & $x$ & \\
\hline Trimmed Flakes and Chips & $X$ & \\
\hline Group I & $x$ & \\
\hline Group II & & $x$ \\
\hline Group III & $x$ & \\
\hline Side & $x$ & \\
\hline End & & $x$ \\
\hline End and Side & $x$ & \\
\hline Ovoid or Rounded & $x$ & \\
\hline Irregular or Indeterminable & $x$ & \\
\hline BIFACES & $x$ & \\
\hline Thick & & $x$ \\
\hline Thin & $x$ & \\
\hline Group I & & $x$ \\
\hline Group II & & $x$ \\
\hline Group III & & $x$ \\
\hline$\overline{\text { Group IV }}$ & $x$ & \\
\hline$\overline{\text { GUNFLINTS AND STRIKE-0-LITES }}$ & $x$ & \\
\hline POSSIBLE GUNFLINTS & $x$ & \\
\hline
\end{tabular}


to be adaptable to small lithic resource materials (Honea 1965:260), is contained in a collection from Mission San José, and may reflect an adaptation to restricted access to $1 i$ thic resources at that site. Indeed, the possible re-use of prehistoric chipped stone artifacts by mission inhabitants also may reflect such an adaptation, if not a limited knowledge of or emphasis on a particular flint-knapping technology.

Also significant is the relatively large amount of chipped stone which appears to represent the final stages of tool production. Core-tools, modified flakes and chips, bifaces, gunflints and strike-0-lites, and possible gunflints make up $23.7 \%$ of the entire mission sample of 2,329 specimens.

The relatively high frequency of occurrence of single-facet platform secondary and tertiary flakes ( $35.3 \%$ of the entire 7 ithic sample) and the relatively low frequency of occurrence of multiple small-facet platform flakes $(3.4 \%$ of the mission sample) probably represent an emphasis of flake-tool production over thin biface tool production. The large number of utilized and trimmed flakes and chips (406 specimens) as compared to the number of bifaces (68 specimens) supports this interpretation. Even considering that much of the chipping debris resulting from thin biface production may have been lost through the 1/4-inch and 1/2-inch screens used for artifact recovery, most of the bifaces in the sample appear to have been produced from flakes.

The sample of gunflints and strike-o-lites, and possible gunflints, is composed of bifaces and trimmed flakes and chips. A few specimens possibly were fashioned from prehistoric thin bifaces. Many gunflints and possible gunflints appear to have been made from blade-like flakes.

In general, the chipped stone sample seems to be representative of a lithic technology concerned primarily with the production of flake-tools for use as projectile points and cutting, scraping, boring and engraving activities, a11 of which probably supplemented a European-introduced technology of metal and stone (Fig. 12).

\section{DISCUSSION}

The preceding paper has presented a morphological description of an assemblage of lithic cultural material thought to be representative of the Spanish Colonial Period occupation of four mission sites in the San Antonio area in Texas. Because mission sites apparently contain some of the only material culture that can be attributed confidently to historic Indian groups, this intensive analysis, aimed at comparative and processual interpretation, should prove to be useful in ongoing problem-oriented ethnohistorical/archaeological research. Following is a series of questions generated from this study.

1. What is the cultural affiliation of the chipped stone found at San Antonio missions?

The occurrence of European-made gunflints in the collections certainly represents a European 7ithic techology focusing on the production of blades (Smith 1960). A7though it seems logical to assume that most 



Figure 12. Products and By-Products of Mission Lithic Tool Production. 
of the mission sample is representative of the lithic technology(ies) of the mission Indians (primarily Coahuiltecan speakers), and was carried over as an adaptation of pre-mission, and perhaps prehistoric, technologies, it also is possible that some mission chipped stone forms other than gunflints and strike-0-1ites actually were produced by the Spanish colonists themselves as part of their subsistence technology, and that this influenced the methods of lithic tool production employed by mission neophytes.

It should also be mentioned that during the mid-eighteenth century, families of Tlaxcaltecan Indians from southern Mexico accompanied the Spanish in the colonization of different parts of Texas (Bolton 1970:345). A7though it is not known that Tlaxcaltecans actually lived in the San Antonio area missions, future research should consider the possibility that these people, who served as teachers of neophytes in other missions, influenced the technology(ies) of lithic tool production employed during the Spanish Colonial Period in Texas.

2. Studying problems of acculturation exemplified by the sixteenth century Spanish conquest of the New World, George Foster (1960:101) suggests that, "With metal tools, domestic animals, new agricultural crops, and the plow, the Spanish forms encountered little competition in existing indigenous forms." How important was the use of chipped stone tools as part of Spanish Colonial technology in the San Antonio area?

Although not well understood, the importance of the use of chipped stone by the prehistoric aboriginal populations of central and south Texas probabily varied, depending upon various cultural and environmental factors. Judging from the frequency of occurrence of chipped stone at mission sites, it is evident that the use of 1 ithic tools was a necessary part of mission subsistence. There is some evidence to suggest that the Spanish colonists may have depended to some extent on chipped stone. The need for gunflints, of course, seemed obvious. Also, it is known that at times the missions and the civil settlement of San Fernando (San Antonio de Bexar) had limited supplies of metal (Hatcher 1935:69,142,146,237; Fox 1977) for which 1ithic materials may have been substituted. Chipped stone artifacts have been reported from two Spanish Colonial Period sites in the civil settlement, the San Fernando Cathedral (Fox, Scurlock and Clark 1977) and the Governor's Palace (Fox 1977). However, the exact cultural chronological affiliation of this material is uncertain.

3. How might the lithic technology represented at the San Antonio missions reflect various aspects of cultural and technological change in Spanish Colonial Texas?

By the beginning of the mission period in Texas, the native peoples of the area had adapted through over 200 years to population decline, territorial displacement, segregation and ideological pressure, loss of ethnic identity, and absorption by invading populations (Campbel1 1975:2). Spanish accounts indicate that most mission Indians 
quickly adopted a common language, dress and customs (Solis 1931; Morfi 1935), all of which appear to have developed from a mixed Indian and Spanish Colonial heritage. The occurrence of relatively similar forms of chipped stone tools at different mission sites may represent a generally common lithic technology which developed to conform to a new cultural identity among mission neophytes. Mission forms of chipped stone appear to be somewhat different from lithic cultural material reported from one early historic site, the probable site of La Salle's Fort St. Louis on the Texas coast (Gilmore 1973). If the chipped stone recovered from this site is representative of some of the historic period peoples who later were gathered into the missions, the differences exhibited by the mission lithic collections might reflect changes in lithic technology which took place during succeeding years of Spanish colonization.

However, there also is some possible evidence of the retention of cultural identity among the mission Indians. As observed previousiy, "chopper-like" core-tools from various mission sites are quite similar to chipped stone implements reported from prehistoric sites in south and south-central Texas. The emphas is on flake-tool production reflected by the chipping debris sampled from mission sites could be an outgrowth of a prehistoric tradition of flake-tool production suggested by Hester (1975a) for south Texas. Tunnell and Newcomb (1969:118) have proposed that the triangular shape of many Group IV thin bifaces (mission arrow points) originally may have been an Apache form, although it can be suggested that a triangular, or subtriangular, form of projectile point might be the simplest form to mass-produce in a Spanish Colonial mission setting.

4. While many Indian groups were "civilized" rather quickly, it appears from Spanish accounts that some moved about from mission to mission, or left the missions to return to the countryside (Habig 1968:41,44, 91). Apparently, some coastal Indian groups brought to the San Antonio missions were very difficult to acculturate (Habig 1968:84-85). Could the evidence of bipolar flaking technology contained in the lithic sample from mission San Jose be representative of occupation by coastal groups?

5. Perhaps the problem of broadest significance to historic and prehistoric archaeology in Texas concerns the possibility that prehistoric lithic forms were picked up and re-used by mission Indians. Is it possible that such a practice was customary during the prehistoric period; and if so, how would this borrowing affect archaeologists' prehistoric sequences of temporally diagnostic lithic forms? 


\section{REFERENCES CITED}

Adams, R. E. W. and T. R. Hester

1973 Letter to Dr. Fred Wendorf, Chairman, Texas Antiquities Committee, concerning completion of excavations at Mission San Antonio de Valero, November 26.

Bolton, H. E.

1970 Texas in the Middle Eighteenth Century: Studies in Spanish Colonial History and Administration. University of Texas Press, Austin.

Bradley, B. A.

1975 Lithic Reduction Sequences: A Giossary and Discussion. In: Lithic Technology: Making and Using Stone Tools, edited by Earl Swanson, pp. 5-13. Mouton Publishers, Paris.

Briggs, A. K.

1971 An Archeological Survey of Ingram Reservoir. Texas Historical Survey Committee and Texas water Development Board, Archeological Survey Report 9.

Campbe11, T. N.

1973 Systematized Ethnohistory and Prehistoric Culture Sequences in Texas. Bulletin of the Texas Archeological Society 43 (for 1972): $1-11$.

1975 The Payaya Indians of Southern Texas. Southern Texas Archaeological Association, Special Publication 1. San Antonio.

Clark, J. W., Jr.

1976 The Sugar Industry at Mission San José y San Miguel de Aguayo. Bulletin of the Texas Archeological Society 47:245-259.

1978 Mission San José y San Miguel de Aguayo: Archeological Investigations, December 1974. Office of the State Archeologist, Texas Historical Commission, Report 29.

Foster, G. M.

1960 Culture and Conquest: America's Spanish Heritage. Viking Fund Publications in Anthropology 27. Quadrangle Books, Chicago.

Fox, A. A.

1977 The Archaeology and History of the Spanish Governor's Palace Park. Center for Archaeological Research. The University of Texas at San Antonio, Archaeological Survey Report 31. 
Fox, A, A., F. A. Bass, Jr. and T. R. Hester

1976 The Archaeology and History of Alamo Plaza. Center for Archaeological Research, The University of Texas at San Antonio, Archaeological Survey Report 16.

Fox, A. A. and T. R. Hester

1976 Archaeological Test Excavations at Mission San Francisco de la Espada. Center for Archaeological Research. The University of Texas at San Antonio, Archaeological Survey Report 22.

Fox, D. E.

1970 Archaeological Salvage at Mission San José, December 1969, April and August 1970. Report prepared by the Texas Historical Survey Comittee, Austin.

Fox, D. E., R. J. Mallouf, N. O'Malley and W. M. Sorrow

1974 Archeological Resources of the Proposed Cuero I Reservoir, De Witt and Gonzales Counties, Texas. Texas Historical Commission and Texas water Development Board, Archeological Survey Report 12.

Fox, D. E., D. Scurlock and J. W. Clark, Jr.

1977 Archeological Excavations at San Fernando Cathedral, San Antonio, Texas: A Preliminary Report. Office of the State Archeologist, Texas Historical Commission, Special Report 22.

Gilmore, $K$.

1967 A Documentary and Archeological Investigation of Presidio San Luis de las Amarillas and Mission Santa Cruz de San Saba, Menard County, Texas. State Building Commission, Archeological Program Report 9.

1969 The San Xavier Missions: A Study in Historic Site Identification. State Building Commission, Archeological Program Report 16.

1973 The Keeran Site: The Probable Site of La Salle's Fort St. Louis in Texas. Office of the State Archeologist, Texas Historical Commission, Report 24.

1974 Mission Rosario, Archeological Investigations, 1974. Texas Parks and Wildlife Department, Parks Division, Historic Sites and Restoration Branch, Archeological Report 14, Part 2.

Goodwin, G. and K. Basso

1971 Western Apache Raiding and warfare. University of Arizona Press, Tucson. 
Greer, J. W.

1967 A Description of the Stratigraphy, Features and Artifacts from an Archeological Excavation at the Alamo. State Building Commission, Archeological Program Report 3.

Habig, M. A.

1968 San Antonio's Mission San José. The Naylor Company, San Antonio. Hamilton, T. M.

1960 Additional Comments on Gunflints. In: Indian Trade Guns, compiled and arranged by T. M. Hamilton, pp. 73-79. Missouri Archaeologist 22.

Hatcher, M. A. (translator and editor)

1935 Letters of Antonio Martinez, the Last Spanish Governor of Texas, 1817-1822. Southwestern Historical Quarterly 34:66-332.

Hester, T. R.

1971 Archeological Investigations at the La Jita Site, Uvalde County, Texas. Bulletin of the Texas Archeological Society 42:51-148.

1975a Chipped Stone Industries of the Rio Grande P1ain, Texas: Some Preliminary Observations. Texas Journal of Science 26(1-2):213-222.

1975b Material Culture at San Bernardo: Preliminary Comments. In: Archaeology and Ethnohistory of the Gateway Area, Middle Rio Grande of Texas:23-36. Report submitted to the National Endowment for the Humanities by The University of Texas at San Antonio. Mimeographed.

1976a Notes on the Non-Ceramic Artifacts from Missions San Juan Bautista and San Bernardo:1976 Season. In: The Archaeology and Ethnohistory of the Gateway Area, Middle Rio Grande of Texas, Report of the 1976 Investigations (Assembled by R. E. W. Adams). Submitted to the National Endowment for the Humanities by The University of Texas at San Antonio. Mimeographed.

1976b Hunters and Gatherers of the Rio Grande Plain and Lower Coast of Texas. Center for Archaeological Research, The University of Texas at San Antonio.

1977 The Lithic Technology of Mission Indians in Texas and Northeastern Mexico. Lithic Technology 6(1-2):9-12.

Hester, T. R., D. Gilbow and A. D. Albee

1973 A Functional Analys is of "Clear Fork" Artifacts from the Rio Grande Plain of Texas. American Antiquity 38:90-96. 
Hester, T. R. and T. C. Hi11, Jr.

1973 Prehistoric Occupation at the Holdsworth and Stewart Sites on the Rio Grande Plain of Texas. Bulletin of the Texas Archeological Society 43:33-65.

Honea, K. H.

1965 The Bipolar Flaking Technique in Texas and New Mexico. Bulletin of the Texas Archeological Society 36:259-267.

Kobayaski, H.

1975 The Experimental Study of Bipolar Flakes. In: Lithic Technology: Making and Using Stone Tools, edited by Earl Swanson, pp. 115-127. Mouton Publishers, Paris.

Lynn, W. M., D. E. Fox and N. O'Malley

1977 Cultural Resource Survey of Choke Canyon Reservoir, Live Oak and McMullen Counties, Texas. Texas Historical Commission, Archeological Survey Report 20.

Mallouf, R. J., D. E. Fox and A. K. Briggs

1973 An Assessment of the Cultural Resources of Palmetto Bend Reservoir, Jackson County, Texas. Texas Historical Commission and Texas Water Development Board, Archeological Survey Report 11.

Morfi, J. A.

1935 History of Texas, 1673-1779. Translated with biographical introduction and annotations by C. E. Castañeda. Quivira Society

Publications 6 (2 Vols.), Albuquerque.

Movius, H. L., Jr.

1974 The Abri Pataud Program of the French Upper Paleolithic in Retrospect. In: Archaeological Researches in Retrospect, edited by G. R. Willey, pp. 87-116: Winthrop Pub1ishers, Inc., Cambridge.

Newcomb, W. W., Jr.

1960 Indian Tribes of Texas. In "A Review of Texas Archeology," edited by E. B. Jelks, E. M. Davis and H. F. Sturgis. Bulletin of the Texas Archeological Society 29 (for 1958):1-34.

Ramsde11, C.

1968 San Antonio: A Historical and Pictorial Guide. The University of Texas Press, Austin. 
Rouse, I.

1960 The Classification of Artifacts in Archeology. American Antiquity $25(3): 313-323$.

Santos, R. G.

1966 Excerpt from the Preliminary Survey of the San Fernando Archives of San Antonio, Texas. Tribal Affiliations and Casters Recorded in the Marriage Records of Mission Purísima Concepción de Acuña from 1733 to 1789 . Office of the County Clerk, Bexar County, Texas.

Schuetz, M. K.

1966 Historic Background of the Mission San Antonio de Valero. State Building Comission, Archeological Program Report 1.

1968 The History and Archeology of Mission San Juan Capistrano, San Antonio, Texas (Vol. 1). Historical Documentation and Description of the Structures. State Building Commission, Archeological Program Report 10.

1969 The History and Archeology of Mission San Juan Capistrano, San Antonio, Texas (Vol. 2). Description of the Artifacts and Ethnohistory of the Coahuiltecan Indians. State Building Commission, Archeological Program Report 11.

1970 Excavation of a Section of the Acequia Madre in Bexar County, Texas, and Archeological Investigations at Mission San Josê in Aprị, 1968. Texas Historical Survey Committee, Archeological Program Report 19.

1973 Archeological Investigations at Mission San Antonio de Valero, the Second Patio. Unpublished manuscript, Office of the State Archeologist, Texas Historical Commission, Austin.

1974 The Dating of the Chapel at Mission San Juan Capistrano, San Antonio, Texas. Office of the State Archeologist, Texas. Historical Commission, Special Report 12.

Scurlock, D. and D. E. Fox

1977 An Archeological Investigation at Mission Concepciốn, San Antonio, Texas. Office of the State Archeologist, Texas Historical Commission, Report 28.

Scurlock, D. and T. P. Powers, Jr.

1975 Interim Report for Mission Concepción (Archeological Investigations), San Antonio, Bexar County, Texas. Office of the State Archeologist, Texas Historical Commission, Special Report 7. 
Shafer, H. J.

1969 Archeological Investigations in the Robert Lee Reservoir Basin, West Centra1 Texas. Papers of the Texas Archeological Salvage Project 17.

Skinner, S.

1971 Prehistoric Settlement of the De Cordova Bend Reservoir, Central Texas. Bulletin of the Texas Archeological Society 42:149-269.

Smith, C. S.

1960 Manufacture of Gunflints in France. In: Indian Trade Guns, compiled and arranged by T. M. Hami1ton. Missouri Archaeologist 22: 40-49.

Solis, G. J. de

1931 The Solis Diary of 1767 . Translated by Peter P. Forrestal. Preliminary Studies of the Texas Catholic Historical Society 1(6). Austin.

Sorrow, W. M.

1972 Archeological Salvage Excavations at the Alamo (Mission San Antonio de Valero), 1970. Texas Archeological Salvage Project, Research Report 4.

Suhm, D. A., A. D. Krieger and E. B. Jelks

1954 An Introductory Handbook of Texas Archeology. Bulletin of the Texas Archeological Society 25.

Tax, S.

1975 General Editor's Preface. In: Lithic Technology: Making and Using Stone Tools, edited by Earl Swanson, pp. v-vii. Mouton Publishers, Paris.

Tunne11, C. D.

1966 A Description of Enameled Earthenware from an Archeological Excavation at Mission San Antonio de Valero (the Alamo). State Building Commission, Archeological Program Report 2.

Tunne11, C. D. and J. R. Ambler

1967 Archeological Excavations at Presidio San Agustín de Ahumada. State Building Commission, Archeological Program Report 6. 
Tunne11, C. D. and W. W. Newcomb, Jr.

1969 A Lipan Apache Mission: San Lorenzo de 1a Cruz, 1762-1771. Texas Memorial Museum Bulletin 14.

Wilmsen, E. N.

1974 Lindenmeier: A Pleistocene Hunting Society. Harper and Row, New York. 